\title{
Post-Larval Teleosteans collected near Plymouth during the summer of 1914.
}

\author{
By \\ E. J. Allen, D.Sc., F.R.S., \\ Director of the Plymouth Laboratory. \\ With 8 Figures in the Text.
}

In Volume X, No. 2, of this Journal issued in June, 1914, Mr. R. S. Clark published an account of the post-larval fishes collected during the years 1906 to 1913 with the Petersen Young-fish Trawl in the neighbourhood of Plymouth. Similar collections were continued regularly under Mr. Clark's supervision, with the assistance of Mr. E. Ford and Mr. F. M. Gossen, from April to July, 1914, and two or three hauls were made in August and September of that year. At the beginning of August Mr. Clark joined Sir Ernest Shackleton's expedition to the Antarctic and left Plymouth in the "Endurance." The young fishes had for the most part been picked out from the general material collected by the youngfish trawl by Messrs. Ford and Gossen, and it is this collection of young fishes which forms the subject of the present report.

In drawing up the report I have followed closely the arrangement adopted by Mr. Clark for the earlier material, and it should be regarded throughout as being supplementary to his paper (1914). For most of the important fishes I have given a monthly summary of the number of specimens captured during the whole period 1906 to 1914, which includes both the figures given by Clark and those now added. The average number of specimens taken per haul of the trawl has also been given for each month. For many reasons, however, these averages cannot claim any great degree of accuracy, but they are, I think, useful as giving a general idea of the relative frequency in the different months. The following sources of error must be borne in mind when drawing conclusions from the averages. The duration of the hauls has been in most cases twenty minutes, but there are a few instances where the time was fifteen minutes and a few where it was thirty minutes. The error introduced by regarding all the hauls as of equal duration will be so small that it will hardly show in the average figures given. 
A more important error will be caused by the fact that the hauls are not distributed with any uniformity over the whole area. The great majority were, however, made outside the 20 -fathom line where the conditions are moderately uniform, but in calculating the averages these have not been separated from the hauls made nearer the shore and in the bays.

Some of the hauls were made at the surface, some at midwater, and some near the bottom, whilst some few are night hauls, which seem to yield larger numbers, especially at the surface, than those made during the day. These circumstances will all tend to diminish the accuracy of the averages, but they do not, I think, destroy their more general significance.

The number of hauls made in each month varies considerably, but from May to September the totals are fairly large (Table II). The number of hauls made in the different years for any given month, as will be seen from the same table, varies so very much that it is not possible to make reliable comparisons of the frequency of any species from year to year.

Another source of error is introduced by the fact that the material of which the young-fish trawl is constructed is not altogether satisfactory, and the size of the mesh often differs considerably in different samples, so that even two new trawls may have different catching powers. With use also the material shrinks badly, the meshes become smaller and the amount of water filtered through the net (and hence the catching power) is greatly diminished. All these circumstances make the numerical results approximate only.

Table I gives the list of stations at which hauls were made in 1914 . The Chart Area, to which each haul is assigned, is that shown on the chart published in Clark's Report (1914). 
TABLE I. LIST OF STATIONS.

Explanation of abbreviations. S. =surface. M. = midwater. B.=bottom. M.H.= midnight haul (between 10 p.m. \& 2 a.m.).

\begin{tabular}{|c|c|c|c|c|c|c|c|c|c|c|}
\hline No. of haul. & Date. & $\begin{array}{c}\text { Depth } \\
\text { of } \\
\text { capture. }\end{array}$ & $\begin{array}{l}\text { Duration of } \\
\text { haul in } \\
\text { minutes. }\end{array}$ & Locality. & & & & & $\begin{array}{l}\text { Total depth } \\
\text { in fathoms. }\end{array}$ & $\begin{array}{c}\text { Chart } \\
\text { area. }\end{array}$ \\
\hline V. & 29.iv.14 & B. & 20 & Eddystone S. by W. 4 miles & . & . & . & . & 28 & S. \\
\hline VI. & , & M. & 20 & Rame N.E. by E. $4 \frac{1}{2}$ miles & $\cdot$ & . & . & . & 28 & S. \\
\hline VII. & , & S. & 20 & Rame N.E. $3 \frac{1}{2}$ miles & $\cdot$ & . & . & 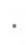 & 28 & $\mathrm{~T}$. \\
\hline VIII.(1) & 8.v.14 & M. & 25 & Cawsand . . . & . & . & . & . & . $\angle 10$ & T.U. \\
\hline VIII.(2) & , & M. & 20 & Cawsand . . . . & . & . & . & . & . $\angle 10$ & T.U. \\
\hline IX.(1) & 15.v.14 & M. & 20 & Bigbury Bay (west part). & . & . & . & . & . ca. 10 & W.Y. \\
\hline IX.(3) & , & S. & 20 & Bigbury Bay (central). & . & . & . & 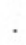 & . ca. 14 & Y. \\
\hline IX.(5) & , & B. & 20 & Bigbury Bay (east of B. Island & & . & . & . & . ca.12-14 & Y. \\
\hline $\mathrm{X}$. & 19.v.14 & M. & 20 & Eddystone N. by E. 5 miles & . & & & 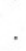 & 37 & O. \\
\hline $\mathrm{XI}$. & , & S. & 20 & Eddystone N. $5 \frac{1}{2}$ miles. М.H. & & & & & 38 & R. \\
\hline XII. & , , & S. & 20 & Eddystone N. 6 miles. M.H. & . & & . & 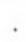 & 39 & R. \\
\hline XIII. & , & M. & 20 & Eddystone N. $6 \frac{1}{2}$ miles. M.H. & . & . & . & . & 39 & Q. \\
\hline XIII.a & 22.v.14 & - & 20 & Eddystone S.W. 3 miles . & . & . & . & . & 28 & S. \\
\hline XIV. & $25 . v .14$ & M. & 20 & Eddystone N. 4 miles. M.H. & . & . & . & . & $35-36$ & R. \\
\hline $\mathrm{XV}$. & , & S. & 20 & Eddystone N. $4 \frac{1}{2}$ miles. M.H. & & . & . & . & 36 & R. \\
\hline XVI. & , & S. & 20 & Eddystone N. 5 miles. M.H. & . & ; & . & & 37 & $\mathrm{R}$. \\
\hline XVII. & 3.vi.14 & B. & 20 & Rame E. 4 miles & . & & & . & 26 & $\mathrm{~T}$. \\
\hline XVIII. & , & B. & 20 & Rame E. $4 \frac{1}{2}$ miles & ${ }^{\circ}$ & . & . & . & 27 & M. \\
\hline XIX. & $"$ & M. & 20 & Rame E. $4 \frac{1}{2}$ miles & . & . & $\cdot$ & $\cdot$ & 27 & M. \\
\hline $\mathrm{XX}$ & 10.vi.14 & S.-M. & 20 & Rame E. 7 miles. M.H. . & . & $\cdot$ & • & . & $\begin{array}{l}27 \\
27\end{array}$ & M. \\
\hline XXI. & 11.vi.14 & M. & 20 & Rame E. 7 miles. М.H. . & ${ }^{\circ}$ & & & . & $\begin{array}{l}27 \\
27\end{array}$ & M. \\
\hline XXII. & ,, & M.-B. & 20 & Rame E. 7 miles. M.H. . & . & . & . & · & $\begin{array}{l}27 \\
27\end{array}$ & $\begin{array}{l}\text { M. } \\
\text { M. }\end{array}$ \\
\hline
\end{tabular}


TABLE I. LIST OF STATIONS.

Explanation of abbreviations. S.=surface. M. =midwater. B.=bottom. M.H.=midnight haul (between 10 p.m. \& 2 a.m.).

\begin{tabular}{|c|c|c|c|c|c|c|c|c|c|c|}
\hline No. of haul. & Date. & $\begin{array}{c}\text { Depth } \\
\text { of } \\
\text { capture. }\end{array}$ & $\begin{array}{l}\text { Duration of } \\
\text { haul in } \\
\text { minutes. }\end{array}$ & Locality. & & & & & $\begin{array}{l}\text { Total depth } \\
\text { in fathoms. }\end{array}$ & $\begin{array}{l}\text { Chart } \\
\text { area. }\end{array}$ \\
\hline XXIII. & 11.vi.14 & B. & 20 & Rame E. 7 miles. M.H. . & & . & . & & 27 & M. \\
\hline XXIV. & 16.vi.14 & B. & 20 & Between Penlee and Rame Hea & $\mathrm{ad}$ & . & . & . & . ca. 15 & T: \\
\hline XXV. &, & B. & 20 & Rame E. $1 \frac{1}{2}$ miles & . & & & . & . 22 & $\mathrm{~T}$ : \\
\hline XXVI. & ,, & B. & 20 & Rame E. 3 miles . & . & . & . & . & 23 & T: \\
\hline XXVII. & , & M. & 20 & Rame E. 5 miles . & . & . & . & . & 27 & M. \\
\hline XXVIII. & , & B. & 15 & Eddystone S.S.W. 3 miles (Mos & squito & o net & YFT.) & . & 29 & S: \\
\hline XXIX. & 17.vi.14 & B. & 20 & Off Rame Head 2 miles . & . & . & & . & 15 & $\mathrm{~T}$ : \\
\hline $\mathrm{XXX}$ & , & M. & 20 & Off Rame Head 2 miles . & . & . & . & . & 11 & $\mathrm{~T}$. \\
\hline XXXI. & , & M. & 20 & Rame Head N. by E. $4 \frac{1}{2}$ miles & & . & & . & 28 & S: \\
\hline XXXII. & ," & $\mathrm{S}$. & 20 & Eddystone S.W. 2 miles & . & & . & . & 29 & S. \\
\hline XXXIII. & 19.vi.14 & M. & 20 & Looe Island N.N.E. 5 miles & . & . & . & . & 28 & M. \\
\hline XXXIV. & , & M. & 20 & Looe Island N. by E. 5 miles . & . & & . & . & 29 & M. \\
\hline XXXV. & , & M. & 20 & Eddystone S.S.E. $4 \frac{1}{2}$ miles & & & & & 28 & N. \\
\hline XXXVI. & 24.vi.14 & B. & 20 & Eddystone W: by N. $\frac{1}{2}$ mile & & & . & . & 23 & S. \\
\hline XXXVII. & , & B. & 20 & Eddystone N.N.W. 1 mile & . & . & . & . & 32 & S. \\
\hline XXXVIII. & , & M. & 20 & Eddystone N. $2 \frac{1}{2}$ miles . & . & & & . & 35 & R. \\
\hline XXXIX. & , & S. & 20 & Eddystone N. by E. $3 \frac{1}{2}$ miles & . & . & . & & 37 & 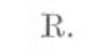 \\
\hline XLI. & 26.vi.14 & B. & 20 & Eddystone N.E. by E. $3 \frac{1}{2}$ miles & & . & . & . & 36 & R. \\
\hline XLII. & 29.vi.14 & B. & 20 & Stoke Point N.E. 4 miles & & . & . & . & 24 & X. \\
\hline XLIII. & , & B. & 20 & Stoke Point N.E. by N. 5 miles & & . & & . & 27 & $\mathrm{X}$. \\
\hline XLIV. & , & M. & 20 & Bolt Tail E. by N. 5 miles & . & . & . & . & 25 & Z. \\
\hline XLV. & , & S. & 20 & Bolt Tail E.N.E. 6 miles . & . & & . & . & 31 & Z. \\
\hline
\end{tabular}


TABLE I. LIST OF STATIONS.

Explanation of abbreviations. S. = surface. M. =midwater. B. =bottom. M.H. =midnight haul (between 10 p.m. \& 2 a.m.).

\begin{tabular}{|c|c|c|c|c|c|c|c|c|c|c|}
\hline No. of haul. & Date. & $\begin{array}{c}\text { Depth } \\
\text { of } \\
\text { capture. }\end{array}$ & $\begin{array}{l}\text { Duration of } \\
\text { haul in } \\
\text { minutes. }\end{array}$ & Locality. & & & & & $\begin{array}{l}\text { Total depth } \\
\text { in fathoms. }\end{array}$ & $\begin{array}{l}\text { Chart } \\
\text { area. }\end{array}$ \\
\hline XLVI. & 2.vii.14 & S. & 20 & Prawle Point N.E. 2 miles. & М.H. & : & . & & 31 & - \\
\hline XLVII. & , & S. & 20 & Prawle Point N.E. by N. 2 & miles. & М.H. & . & . & 31 & - \\
\hline XLVIII. & , & M. & 20 & Start Point N.E. 2 miles . & & . & . & ${ }^{\circ}$ & 27 & - \\
\hline XLIX. & , & M. - B. & 20 & Start Point N.N.E. 2 miles. & М.H. & . & . & ${ }^{\circ}$ & 32 & - \\
\hline $\mathrm{L}$. & 6.vii.14 & B. & 20 & Rame N.N.W: 1 mile & . & . & . & . & 20 & T. \\
\hline LI. & , & B. & 20 & Rame N.N.W. $1 \frac{1}{2}$ miles . & . & . & . & . & 25 & $\mathrm{~T}$. \\
\hline LII. & , & M. & 20 & Rame N.W. by N. $2 \frac{1}{2}$ miles & . & . & & . & 24 & T. \\
\hline LIII. & , & B. & 20 & Cawsand Bay. . . . & & . & . & . & $\angle 10$ & T.U. \\
\hline LIV. & 9.vii.14 & S. & 20 & Looe Is. W.N.W. $\frac{1}{4}$ mile . & . & . & & . & 5 & L. \\
\hline $\mathrm{LV}$. & , & M. & 20 & Looe Is. N.W. 1 mile & & & . & ${ }^{\circ}$ & 10 & M. \\
\hline LVI. & , & B. & 20 & Looe Is. N.N.W. 2 miles . & . & . & & . & 23 & M. \\
\hline LVII. & $"$ & B. & 20 & Looe Is. N. 2 miles & . & & $\cdot$ & ${ }^{\circ}$ & 23 & M. \\
\hline LVIII. & , & M. & 20 & Rame Hd. E. by S. 2 miles & . & . & . & . & 21 & T. \\
\hline LIX. & 15.vii.14 & M. & 20 & Rame E. 4 miles. M.H. . & & . & ${ }^{\circ}$ & . & 26 & T. \\
\hline LX. & , & M. & 20 & Rame E. 4 miles. M.H. . & . & . & . & ${ }^{\circ}$ & 26 & T. \\
\hline LXI. & 16.vii.14 & B. & 20 & Rame E. 6 miles . & & . & . & . & 26 & M. \\
\hline LXII. & " & B. & 20 & Rame E. 7 miles . & . & . & & & 27 & M. \\
\hline LXIII. & 22.vii.14 & B. & 20 & Cawsand Bay . . & & . & & $\cdot$ & . $\angle 10$ & T.U. \\
\hline LXIV. &, & B. & 20 & Between Penlee and Rame & Bottom & . & & ${ }^{\circ}$ & . $10-12$ & T. \\
\hline LXV. & , & B. & 20 & Whitsands E. . . . & . & & . & . & . $\angle 10$ & T.U. \\
\hline LXVI. & , & M. & 20 & Whitsands W. & . & & & & . $\angle 10$ & L. \\
\hline LXVII. & , & M. & 20 & Eddystone E. $1 \frac{1}{2}$ miles . & $\therefore$ & & . & . & 32 & S. \\
\hline
\end{tabular}


Explanation of abbreviations. S.=surface. $\mathrm{M}=$ midwater. B.=bottom. M.H.=midnight haul (between 10 p.m. \& 2 a.m.).

\begin{tabular}{|c|c|c|c|c|c|c|}
\hline No. of haul. & Date. & $\begin{array}{l}\text { Depth I } \\
\text { of } \\
\text { capture. }\end{array}$ & $\begin{array}{c}\text { Duration of } \\
\text { haul in } \\
\text { minutes. }\end{array}$ & Locality. & & \\
\hline LXVIII. & 22.vii.14 & B. & 20 & Eddystone N.E. 4 miles . & . & . \\
\hline LXIX. & ", & S. & 20 & Eddystone N.E. by N. 6 miles & . & . \\
\hline LXX: & , & M & 20 & Eddystone N.E. by N. 6 miles & & . \\
\hline LXXI: & , , & B. & 20 & Eddystone N. by E. 6 miles (M & Mosqui & ito 1 \\
\hline LXXII. & , & B. & 20 & Eddystone N. by E. 6 miles (M & Mosqui & ito \\
\hline LXXIII. & 29.vii.14 & M. & 20 & Eddystone S. $\frac{1}{4}$ mile & . & . \\
\hline LXXIV. & , & M. & 20 & Eddystone S.E. by E. $\frac{1}{4}$ mile & . & . \\
\hline LXXV. & , , & B. & 20 & Eddystone N.E. by N. $\frac{1}{2}$ mile & . & . \\
\hline LXXVI. & , & M. & 20 & Eddystone N. 2 miles : & . & . \\
\hline LXXVII. & ", & B. & 20 & Eddystone N. by W. 2 miles & . & . \\
\hline LXXVIII: & , & M. & 20 & Eddystone S.W. $4 \frac{1}{2}$ miles. & $\cdot$ & . \\
\hline LXXX. & ," & M. & 20 & Whitsand Bay E. . & & · \\
\hline LXXXI. & ," & M. & 20 & Whitsand Bay E. . & . & . \\
\hline LXXXII. & ", & M. & 20 & Whitsand Bay W. . . & . & . \\
\hline LXXXIII. & ", & B. & 20 & Rame E. by S. $3 \frac{1}{2}$ miles . & $\therefore$ & $\therefore$ \\
\hline LXXXIV. & ", & B. & 20 & Rame E. by S. 4 miles (Mosqui & lito ne & et) \\
\hline LXXXV. & 12.viii.14 & M. & 20 & Rame E. by N. 5 miles . & . & . \\
\hline LXXXVI. & " & B.-M. & 20 & Rame E. by N. 4 miles . & . & . \\
\hline LXXXVII. & 4.ix.14 & M. & 30 & Off Penlee . & . & . \\
\hline
\end{tabular}

$\begin{array}{cc}\begin{array}{c}\text { Total depth } \\ \text { in fathoms. }\end{array} & \begin{array}{c}\text { Chart } \\ \text { area. }\end{array} \\ 37 & \text { R. } \\ 38 & \text { Q. } \\ 38 & \text { Q. } \\ 38 & \text { Q. } \\ 38 & \text { Q. } \\ 20 & \text { S. } \\ 20 & \text { S. } \\ 25 & \text { S. } \\ 35 & \text { R. } \\ 35 & \text { R. } \\ 28 & \text { S. } \\ \angle 10 & \text { T.U. } \\ \angle 10 & \text { T.U. } \\ \angle 10 & \text { L. } \\ 23 & \text { T. } \\ 23 & \text { T. } \\ 27 & \text { M. } \\ 26 & \text { T. } \\ 12 & \text { T. }\end{array}$


Table II, showing the Number of Hauls made with the Young-fish Trawl in each month for each of the years from 1906 to 1914 in which investigations were carried on.

\section{Monthly Number of Hauls.}

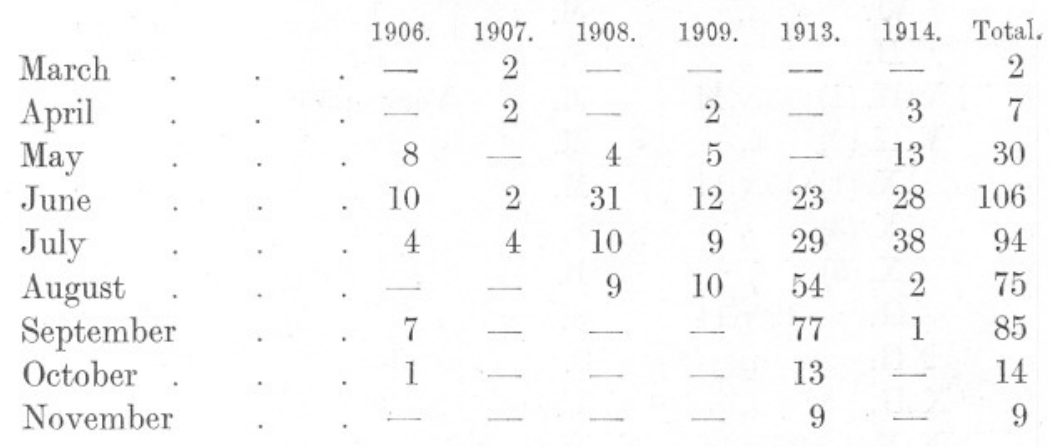

\section{CLUPEID $\nRightarrow$.}

As in the previous years the Clupeidæ show a very marked maximum frequency in May and the first half of June. A considerable number of specimens have been stained and the vertebræ counted. In all cases these have proved to be sprats, and there seems no doubt that the sprat constitutes by far the greater proportion of the specimens taken during the months in which the 1914 material was collected. This is rendered more probable by the fact that the abundance of black pigment in the neighbourhood of the anus, which Ehrenbaum considers to be one of the distinguishing characters of post-larval sprats, was observed in nearly all the specimens examined. Unfortunately in the present state of our knowledge of the early stages of the different species of Clupea, the detection of a few specimens of $C$. harengus or $C$. pilchardus amongst the large quantities of $C$. sprattus which are caught in the young-fish trawl is from a practical point of view impossible, the labour involved in staining and counting the vertebræ of so many specimens being altogether out of proportion to the value of the information which would be gained. 
TABLE III.

Record of Clupea sp.

\begin{tabular}{|c|c|c|c|c|}
\hline $\begin{array}{r}\text { No. of haul. } \\
\text { V. }\end{array}$ & $\begin{array}{c}\text { Date. } \\
\text { 29.iv.14 }\end{array}$ & $\begin{array}{c}\text { Depth. } \\
\text { B. }\end{array}$ & $\begin{array}{l}\text { No. } \\
74\end{array}$ & $\begin{array}{c}\text { Size in nm. } \\
7-16 \cdot 5\end{array}$ \\
\hline VI. & , & M. & 13 & $5 \cdot 6-11 \cdot 5$ \\
\hline VII. & ", & S. & 62 & $6-22$ \\
\hline VIII. (1) & 8.v.14 & M. & Very many & $9 \cdot 5-25$ \\
\hline VIII. (2) & , & M. & 220 & $9 \cdot 5-24$ \\
\hline IX. (1) & 15.v.14 & M. & 54 & $9-22 \cdot 5$ \\
\hline IX. (3) &, & S. & 5 & $12-16 \cdot 5$ \\
\hline IX. (5) & , & B. & 80 & $6-24$ \\
\hline XI. & 19.v.14 & S. & 1 & 16 \\
\hline XII. & , & S. & 460 & $6 \cdot 2-20$ \\
\hline XIII. & , & M. & 406 & $5 \cdot 5-20$ \\
\hline XIV. & 25.v.14 & M. & Very many & $8-25$ \\
\hline XV. & , & S. & Many thousands & \\
\hline XVI. & ", & S. & , & $9-25$ \\
\hline XVII. & 3.vi.14 & B. & 218 & $6 \cdot 7-18 \cdot 5$ \\
\hline XVIII. & , & B. & 415 & $6 \cdot 1-18 \cdot 5$ \\
\hline XIX. & , & M. & 195 & $6-19 \cdot 5$ \\
\hline $\mathrm{XX}$. & 10.vi.14 & S. - M. & Very many & $10 \cdot 5-28$ \\
\hline XXII. & 11.vi.14 & M.-B. & ,, & \\
\hline XXIII. & , & B. & 80 & $14-27$ \\
\hline XXIV. & 16.vi.14 & B. & 7 & $14 \cdot 5-19 \cdot 5$ \\
\hline XXV. & , & B. & 9 & $12 \cdot 3-18 \mathrm{ca}$. \\
\hline XXVI. & , & B. & 7 & 9-17 \\
\hline XXVII. & , & M. & 34 & $11 \cdot 6-20$ \\
\hline XXIX. & 17.vi.14 & B. & 5 & $14-24$ \\
\hline XXXI. & ", & M. & 5 & $11 \cdot 5-23 \cdot 5$ \\
\hline XXXII. & , & S. & 65 & $11 \cdot 5-25$ \\
\hline XXXIV. & 19.vi.14 & M. & 3 & $8 \cdot 2-13$ \\
\hline XXXV. & 3 & M. & 10 & $7 \cdot 2-20 \cdot 5$ \\
\hline XXXVI. & 24.vi.14 & B. & 10 & $7 \cdot 7-14 \cdot 5$ \\
\hline XXXVII. & , & B. & 11 & $7 \cdot 5-19$ \\
\hline XXXVIII. & , & M. & 26 & $7-16$ \\
\hline XXXIX. & ", & S. & 10 & $7 \cdot 5-20$ \\
\hline XLII. & 29.vi.14 & B. & 2 & $10-13$ \\
\hline XLIII. & " & B. & 6 & 9-13 \\
\hline XLIV. & ", & M. & 4 & $9 \cdot 5-11 \cdot 5$ \\
\hline XLV. & , & S. & 1 & $9 \cdot 5$ \\
\hline XLIX. & 2.vii.14 & M. - B. & 71 & $11 \cdot 5-35 \cdot 5$ \\
\hline
\end{tabular}


POST-LARVAL TELEOSTEANS COLLECTED NEAR PLYMOUTH.

TABLE III. (continued).

\begin{tabular}{|c|c|c|c|c|}
\hline $\begin{array}{r}\text { No. of haul. } \\
\text { L. }\end{array}$ & $\begin{array}{l}\text { Date. } \\
\text { 6.vii.14 }\end{array}$ & $\begin{array}{l}\text { Depth. } \\
\text { B. }\end{array}$ & $\begin{array}{c}\text { No. } \\
6\end{array}$ & $\begin{array}{l}\text { Size in mm. } \\
13-28 \mathrm{ca} .\end{array}$ \\
\hline LI. & , & B. & 9 & $11 \cdot 5-19$ \\
\hline LII. & , & M. & 3 & $12-21$ \\
\hline LIII. & , & B. & 1 & 19 \\
\hline LIV. & 9.vii.14 & S. & 7 & $13 \cdot 5-24$ \\
\hline $\mathrm{LV}$. & , & M. & 3 & $15-16 \cdot 5$ \\
\hline LVI. & , & B. & 2 & $17-19$ \\
\hline LVII. & , & B. & 1 & 20 \\
\hline LVIII. & , & M. & 2 & $19 \cdot 5-22$ \\
\hline LIX. & 15.vii.14 & M. & 30 & $13-26$ \\
\hline LX. & , & M. & 35 & $13-29$ \\
\hline LXI. & 16.vii.14 & B. & 89 & $11-26$ \\
\hline LXII. & , & B. & 4 & $12 \cdot 5-17$ \\
\hline LXVII. & 22.vii.14 & M. & 7 & $5 \cdot 7-15 \cdot 5$ \\
\hline LXVIII. & , & B. & 30 & $10-17$ \\
\hline LXIX. & , & S. & 7 & $13-21$ \\
\hline LXX. & , & M. & 2 & $9 \cdot 5-14$ \\
\hline LXXIII. & 29.vii.14 & M. & 1 & 17 \\
\hline LXXV. & ", & B. & 11 & $9 \cdot 5-17$ \\
\hline LXXVII. & ", & B. & 2 & $10-10 \cdot 5$ \\
\hline LXXVIII. & , & M. & 1. & 21 \\
\hline LXXXIII. & , & B. & 1 & 19 \\
\hline LXXXIV. &, & B. & 2 & $21-23$ \\
\hline LXXXVII. & 4.ix.14 & M. & 2 & $20 \cdot 5-22 \cdot 3$ \\
\hline
\end{tabular}

SYNGNATHID丑.

Only six specimens belonging to this family are present in the material, the small number being due to the fact that most of the hauls were made at considerable distances from the shore. The four hauls in which they occurred were made between Penlee and Rame Head and in Whitsand Bay, the total depth of water being in all cases not greater than 15 fathoms.

\section{TABLE IV.}

Record of Syngnathus rostellatus.

$\begin{array}{rcccc}\text { No. of haul. } & \text { Date. } & \text { Depth. } & \text { No. } & \text { Size in mm. } \\ \text { XXIX. } & \text { 17.vi.14 } & \text { B. } & 1 & 26 \cdot 5 \\ \text { LXIV. } & 22 . \text { vii. } 14 & \text { B. } & 1 & 17 \cdot 5 \\ \text { LXXX. } & 29 . \text { vii.14 } & \text { M. } & 2 & 23-30 \cdot 5 \\ \text { LXXXI. } & , & \text { M. } & 2 & 35-52\end{array}$




\section{AMMODYTID A.}

All the specimens of Ammodytes appear to belong to the same species, which is probably $A$. lanceolatus, though as Clark (1914) points out, it is difficult to distinguish between the young stages of $A$. lanceolatus and A. tobianus. Table V. gives the records for 1914, whilst Table VI. gives the monthly totals and averages per haul for all the years 1906-1914 for which records exist. The average shows a gradual rise to a maximum in August and then a sudden drop (cf. Clark (1914), p. 340).

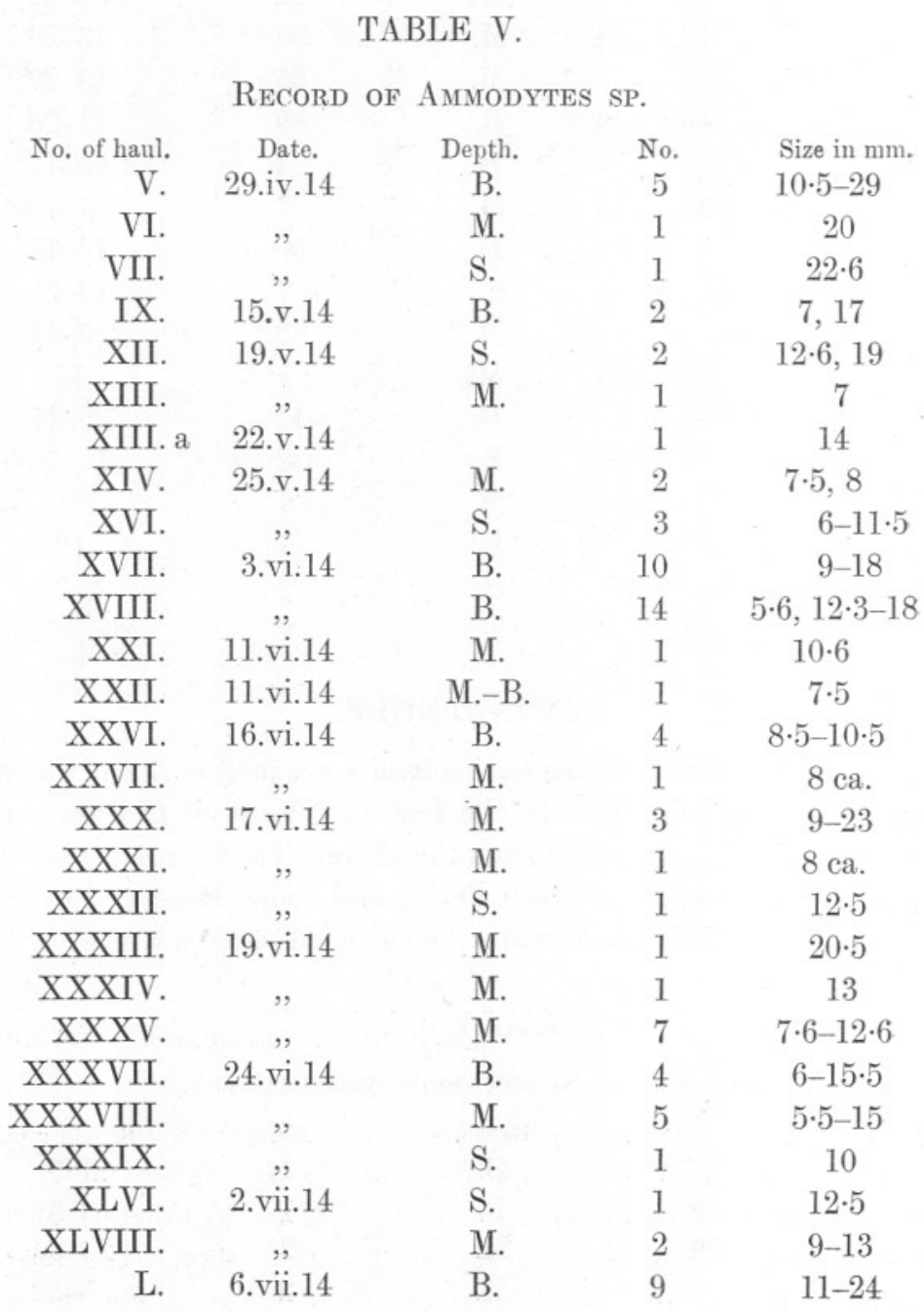




\begin{tabular}{|c|c|c|c|c|}
\hline $\begin{array}{l}\text { No. of haul. } \\
\text { LI. }\end{array}$ & $\begin{array}{l}\text { Date. } \\
\text { 6.vii.14 }\end{array}$ & $\begin{array}{l}\text { Depth. } \\
\text { B. }\end{array}$ & $\begin{array}{c}\text { No. } \\
3\end{array}$ & $\begin{array}{l}\text { Size in mm. } \\
12.5-18.5\end{array}$ \\
\hline LII. & ,, & M. & 3 & 23 ca. \\
\hline LIV. & 9.vii.14 & S. & 1 & $18 \cdot 5$ \\
\hline LVI. & , & B. & 2 & $12-17 \cdot 5$ \\
\hline LVII. & , & B. & 1 & $12 \mathrm{ca}$. \\
\hline LIX. & 15.vii.14 & M. & 7 & $10-16$ \\
\hline LX. & , & M. & 8 & $12-23 \cdot 5$ \\
\hline LXI. & 16.vii.14 & B. & 5 & $13 \cdot 7-30$ \\
\hline LXII. & , & B. & 5 & $15-19 \cdot 5$ \\
\hline LXVI. & 22.vii.14 & M. & 1 & 12 \\
\hline LXVII. & , & M. & 8 & $8-12 \cdot 5$ \\
\hline LXVIII. & , & B. & 16 & $7-14 \cdot 8$ \\
\hline LXIX. & , & S. & 3 & $9-13$ \\
\hline LXXIII. & 29.vii.14 & M. & 2 & $13-15$ \\
\hline LXXIV. & ," & M. & 1 & 12 \\
\hline LXXV. & $"$ & B. & 13 & $6 \cdot 5-15 \cdot 8$ \\
\hline
\end{tabular}

TABLE VI.

\section{Ammodytes sp.}

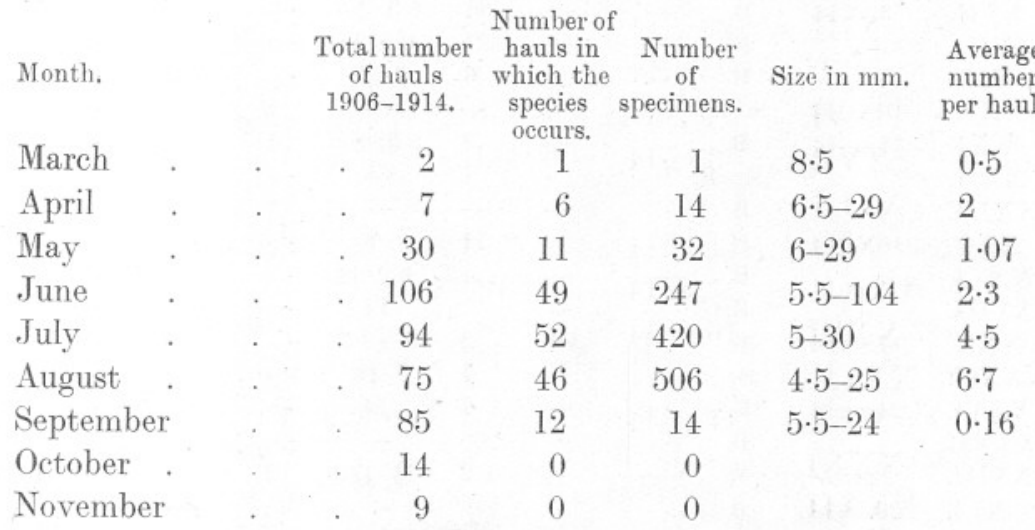

\section{GADID $A$}

Gadus pollachius L. G. merlangus L. G. minutus O. F. Müller. G. luscus L.

Table VII. gives the records of the above species for 1914, whilst Tables VIII. to XI. show the monthly totals and averages of all the records from 1906-1914. The few specimens of $G$. pollachius taken in 1914 were nearly all taken in April and the first half of May. The maximum frequency for the whole period is in March and April. For the whiting 
(G. merlangus) the maximum is in May, whilst in June specimens of the sizes captured by the young-fish trawl are still fairly numerous. May also shows a distinct maximum for $G$. luscus and $G$. minutus. Specimens of all these gadoids are very infrequent in hauls taken after June.

\section{TABLE VII.}

\section{Record of Gadus sp.}

\begin{tabular}{|c|c|c|c|c|c|c|c|c|c|c|}
\hline No. of haul. & Date. & Depth. & $\begin{array}{l}\text { G. } \\
\text { No. }\end{array}$ & $\begin{array}{l}\text { pollachius. } \\
\text { Size in } \mathrm{mm} \text {. }\end{array}$ & $\begin{array}{l}\text { G. } \\
\text { No. }\end{array}$ & $\begin{array}{l}\text { merlangus. } \\
\text { Size in mm. }\end{array}$ & $\begin{array}{r}\text { G. } \\
\text { No. }\end{array}$ & $\begin{array}{l}\text { luseus. } \\
\text { Size in mm. }\end{array}$ & $\begin{array}{l}\text { G. } \\
\text { No. }\end{array}$ & $\begin{array}{l}\text { minutus. } \\
\text { Size in } \mathrm{mm} .\end{array}$ \\
\hline V. & 29.iv.14 & B. & 2 & $6-16 \cdot 5$ & 2 & $6-6 \cdot 5$ & - & - & 6 & $7-14$ \\
\hline VI. & , & M. & - & - & - & - & - & - & 2 & $7 \cdot 5-10 \cdot 5$ \\
\hline VII. & , & S. & 7 & $5 \cdot 5-13$ & - & - & - & - & - & - \\
\hline VIII.(2) & 8. v. 14 & M. & - & - & 1 & 7 & - & - & 1 & $8 \cdot 5$ \\
\hline IX.(1) & 15.v.14 & M. & 4 & $8-10$ & 103 & $5 \cdot 5-11 \cdot 5$ & - & - & - & - \\
\hline IX.(3) & , & S. & 6 & $7 \cdot 5-9 \cdot 5$ & 5 & $8 \cdot 5-10 \cdot 2$ & - & - & - & - \\
\hline IX.(5) & , & B. & - & - & 211 & $6 \cdot 5-15$ & 4 & $6-8$ & 1 & $7 \cdot 5$ \\
\hline X. & 19.v.14 & M. & - & - & 10 & $6-16$ & - & - & - & - \\
\hline XI. & , & S. & 3 & $5 \cdot 5-9$ & 1 & $6 \cdot 5$ & - & - & 2 & $7-9$ \\
\hline XII. & , & S. & 3 & $9 \cdot 6-13$ & 4 & $7-12$ & 5 & $6-9 \cdot 8$ & 16 & $5 \cdot 4-12 \cdot 3$ \\
\hline XIII. & , & M. & - & - & 8 & $5 \cdot 5-8 \cdot 3$ & 7 & $5 \cdot 6-6 \cdot 2$ & 158 & $5 \cdot 5-15$ \\
\hline XIV. & 25.v.14 & M. & - & - & 21 & $7 \cdot 2-14$ & 11 & $6 \cdot 5-16$ & 34 & $6 \cdot 5-16$ \\
\hline XV. & , & $\mathrm{S}$ & - & - & 4 & $8-13$ & 2 & $8-8 \cdot 5$ & 23 & $6 \cdot 7-14$ \\
\hline XVI. & , & S. & 一 & - & 14 & $5 \cdot 5-18$ & 6 & $7 \cdot 8-12 \cdot 7$ & 89 & $6-17$ \\
\hline XVII. & 3.vi.14 & B. & - & - & 31 & $6 \cdot 3-9 \cdot 5$ & - & - & 4 & $5 \cdot 3-8 \cdot 5$ \\
\hline XVIII. &, & B. & - & - & 24 & $6 \cdot 5-11$ & - & - & - & - \\
\hline XIX. & ," & M. & - & - & 6 & $7-13$ & - & - & - & - \\
\hline XX. & 10.vi.14 & S. - M. & - & - & - & - & 1 & $9 \cdot 3$ & - & - \\
\hline XXI. & 11.vi.14 & M. & - & - & 3 & $8 \cdot 5-9 \cdot 5$ & 1 & $9 \cdot 5$ & - & - \\
\hline XXII. & , & M. - B. & - & - & 1 & $8 \cdot 5$ & - & - & 3 & $6 \cdot 5-17 \cdot 7$ \\
\hline XXIII. & , & B. & - & - & - & - & 1 & 7 & 8 & $7 \cdot 6-10$ \\
\hline $\mathrm{XXV}$. & 16.vi.14 & B. & - & - & 1 & 6 & - & - & - & - \\
\hline XXVI. & , & B. & - & - & 4 & $6 \cdot 2-16$ & - & - & - & - \\
\hline XXVIII. & , & B. & - & - & 1 & 11 & - & - & - & - \\
\hline XXX. & 17.vi.14 & M. & 1 & $5 \cdot 6$ & 2 & $8-13.5$ & - & - & - & - \\
\hline XXXII. & , & S. & - & - & 4 & 9-18 & - & - & - & - \\
\hline XXXVI. & 24.vi.14 & B. & - & - & 1 & 14 & - & - & - & - \\
\hline XXXVII. & , & B. & - & - & - & - & - & - & 1 & 18 \\
\hline XXXVIII. & , & M. & - & - & 2 & $11-11 \cdot 5$ & 2 & $5 \cdot 3-5 \cdot 5$ & - & - \\
\hline XLI. & 26.vi.14 & B. & - & - & - & - & - & - & 25 & $11-28$ \\
\hline XLIV. & 29.vi.14 & M. & - & - & 1 & 19 & - & - & - & - \\
\hline XLVI. & 2.vii.14 & S. & - & - & 2 & $25-31$ & 1 & $1 c \cdot 2$ & - & - \\
\hline LV. & 9.vii.14 & M. & ... & - & 1 & $7 \cdot 5$ & - & - & - & - \\
\hline LXVII. & 22.vii. 14 & M. & 1 & 7.2 & - & - & - & - & - & - \\
\hline LXVIII. & , & B. & 一 & - & - & - & - & - & 1 & $8 \cdot 6$ \\
\hline LXXVII. & 29.vii. 14 & B. & 一 & - & - & - & - & - & 1 & $12 \cdot 4$ \\
\hline
\end{tabular}




\section{TABLE VIII}

\section{Gadus pollachius.}

Month.

\begin{tabular}{|c|c|c|c|c|}
\hline $\begin{array}{l}\text { Total number } \\
\text { of hauls } \\
1906-1914 .\end{array}$ & $\begin{array}{l}\text { Number of } \\
\text { hauls in } \\
\text { which the } \\
\text { species } \\
\text { occurs. }\end{array}$ & $\begin{array}{c}\text { Number } \\
\text { of } \\
\text { specimens. }\end{array}$ & Size in $\mathrm{mm}$. & $\begin{array}{l}\text { Average } \\
\text { number } \\
\text { per haul. }\end{array}$ \\
\hline 2 & 2 & 23 & $3-5$ & $11 \cdot 5$ \\
\hline 7 & 4 & 46 & $3 \cdot 5-16 \cdot 5$ & $6 \cdot 6$ \\
\hline 30 & 8 & 21 & $5-22$ & $0 \cdot 7$ \\
\hline 106 & 5 & 20 & $5 \cdot 6-42$ & $0 \cdot 2$ \\
\hline 94 & 2 & 2 & $6-7 \cdot 2$ & $0 \cdot 01$ \\
\hline
\end{tabular}

TABLE IX.

Gadus merlangus.

Month.

Number of

Totalnumber hauls in Number Average of hauls which the of Size in mm. number 1906-1914. species specimens. per haul.

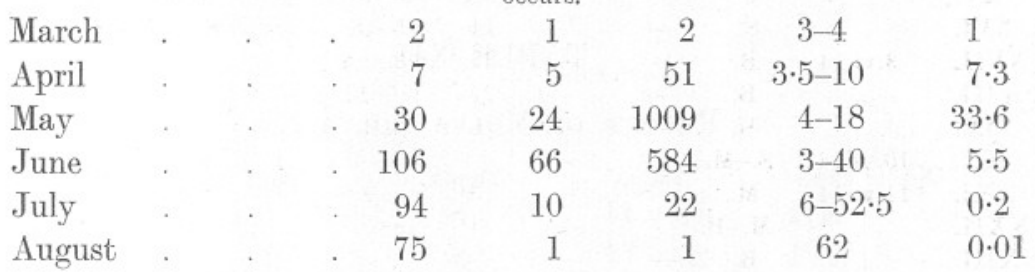

\section{TABLE X.}

\section{Gadus Luscus.}

Month.

Number of

Total number hauls in Number Average of hauls which the of Size in mm. number 1906-1914. species specimens. per haul,

$\begin{array}{llrrrrl}\text { March } & & 2 & 0 & - & - & - \\ \text { April } & & 7 & 3 & 3 & 5 \cdot 5-7 \cdot 5 & 0 \cdot 4 \\ \text { May } & & 30 & 8 & 44 & 5-16 & 1 \cdot 5 \\ \text { June } & & 106 & 13 & 15 & 4-9 \cdot 5 & 0 \cdot 14 \\ \text { July } & . & 94 & 1 & 1 & 10 \cdot 2 & 0 \cdot 01 \\ \text { August } & . & 75 & - & - & - & - \\ \text { September } & . & 85 & 5 & 5 & 4-8 & 0 \cdot 06 \\ \text { October } & & 14 & 4 & 5 & 3 \cdot 4-4 \cdot 9 & 0 \cdot 36 \\ \text { November } & & 9 & 1 & 1 & 3 \cdot 1 & 0 \cdot 1\end{array}$


TABLE XI.

\section{Gadus minutus.}

\begin{tabular}{|c|c|c|c|c|}
\hline Month. & $\begin{array}{c}\text { Total number } \\
\text { of hauls } \\
1906-1914 .\end{array}$ & $\begin{array}{l}\text { Number of } \\
\text { hauls in } \\
\text { which the } \\
\text { species } \\
\text { occurs. }\end{array}$ & $\begin{array}{c}\text { Number } \\
\text { of } \\
\text { specimens. }\end{array}$ & Size in $\mathrm{mm}$. \\
\hline
\end{tabular}

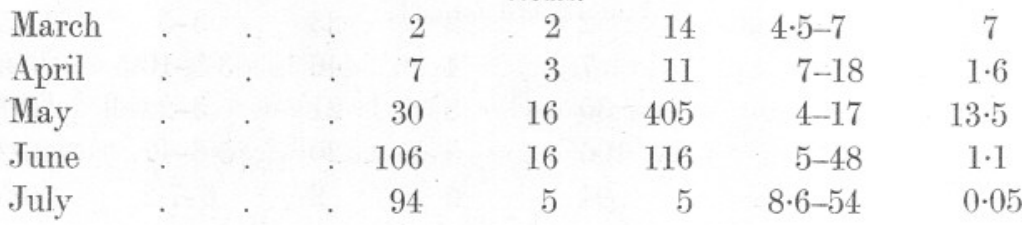

GADIDÆ.

Molva molva L.

During the period 1906-13, eight post-larval specimens of Molva molva were taken in May and twenty-two in June.

\section{TABLE XII.}

Record of Molva molva L.

$\begin{array}{rrccl}\text { No. of haul. } & \text { Date. } & \text { Depth. } & \text { No. } & \text { Size in mm. } \\ \text { XII. } & 19 . \mathrm{v} .14 & \text { S. } & 1 & 10 \cdot 3 \\ \text { XVI. } & 25 . v .14 & \text { S. } & 2 & 8 \cdot 6-11 \\ \text { XVII. } & 3 . v i .14 & \text { B. } & 1 & 8 \\ \text { XXII. } & 11 . v i .14 & \text { M. } & 2 & 8 \cdot 5-10 \cdot 5 \\ \text { XXVIII. } & 16 . v i .14 & \text { B. } & 1 & 8 \cdot 6 \\ \text { XXXVIII. } & 24 . v i .14 & \text { M. } & 1 & 12 \cdot 5 \\ \text { XLIV. } & 29 . \text { vi. } 14 & \text { M. } & 1 & 10 \text { ca. } \\ \text { L. } & 6 . v i i .14 & \text { B. } & 1 & 20 \text { ca. }\end{array}$

\section{GADID $\approx$.}

\section{Raniceps raninus $\mathrm{L}$.}

The single specimen of the lesser forkbeard taken in 1914 was obtained at the end of July. Previous records of post-larvæ of the species at Plymouth are all due to Clark who obtained eight specimens in August and September, 1913. 


\section{TABLE XIII.}

ReCord of Raniceps Raninus L.

$\begin{array}{ccccc}\text { No. of haul. } & \text { Date. } & \text { Depth. } & \text { No. } & \text { Size in mm. } \\ \text { LXXIII. } & 29 . \text { vii. } 14 & \text { M. } & 1 & 8\end{array}$

$$
\text { GADID } Æ .
$$

Onos mustelus L.

All the post-larval rocklings have been identified as $O$. mustelus. The differences between the species are not, however, very well defined, and it is possible that a few of the specimens may belong to $O$. tricirratus Bl. or to O. cimbrius L.

\section{TABLE XIV.}

Record of Onos mustelus L.

\begin{tabular}{|c|c|c|c|c|}
\hline $\begin{array}{l}\text { No. of haul, } \\
\text { V. }\end{array}$ & $\begin{array}{c}\text { Date. } \\
\text { 29.iv.14 }\end{array}$ & $\begin{array}{l}\text { Depth. } \\
\text { B. }\end{array}$ & $\begin{array}{c}\text { No. } \\
2\end{array}$ & $\begin{array}{c}\text { Size in } \mathrm{mm} . \\
4 \cdot 8-8 \cdot 5\end{array}$ \\
\hline VII. & , & S. & 6 & $4 \cdot 5-6 \cdot 5$ \\
\hline IX. (1) & 15.v.14 & M. & 3 & $6 \cdot 6-7 \cdot 3$ \\
\hline IX. (3) & , & S. & 1 & $6 \cdot 5$ \\
\hline IX. (5) & , & B. & 1 & 6 \\
\hline $\mathrm{X}$ & 19.v.14 & M. & 5 & $5 \cdot 4-10$ \\
\hline XII. & , & S. & 3 & $6 \cdot 1-11$ \\
\hline XIII. & , & M. & 5 & $5-8 \cdot 5$ \\
\hline XIV. & $25 . \mathrm{v} \cdot 14$ & M. & 7 & $5-16$ \\
\hline $\mathrm{XV}$. & , & S. & 5 & $6-15 \cdot 6$ \\
\hline XVI. & , & S. & 14 & $6 \cdot 5-15 \cdot 5$ \\
\hline XVIII. & 3.vi.14 & B. & 2 & $7-7 \cdot 5$ \\
\hline XIX. & , & M. & 1 & $6 \cdot 8$ \\
\hline XXI. & 11.vi.14 & M. & 1 & 31 \\
\hline XXII. & , & M.-B. & 1 & $28 \cdot 5$ \\
\hline XXIV. & 16.vi.14 & B. & 3 & $7-25$ \\
\hline XXXI. & 17.vi.14 & M. & 2 & $5 \cdot 2$ \\
\hline XXXII. & , & S. & 2 & $5 \cdot 5$ \\
\hline XXXVIII. & 24.vi.14 & M. & 3 & $5 \cdot 3-6 \cdot 5$ \\
\hline XXXIX. & , & S. & 1 & $6 \cdot 5$ \\
\hline XLVI. & 2.vii.14 & S. & 2 & $6 \cdot 3-8 \cdot 5$ \\
\hline XLVIII. & " & M. & 1 & 7 \\
\hline XLIX. & ", & M.-B. & 1 & $9 \cdot 8$ \\
\hline LIX. & 15.vii.14 & M. & 2 & $8 \cdot 8-31$ \\
\hline LX. & ", & M. & 4 & $12-32$ \\
\hline LXXIII. & 29.vii.14 & M. & 1 & $7 \cdot 5$ \\
\hline
\end{tabular}




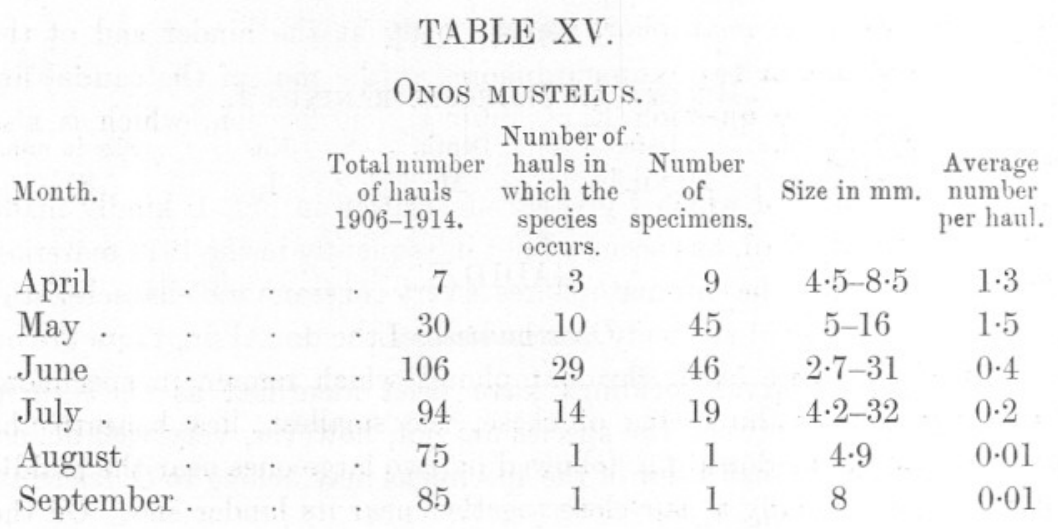

\section{SERRANID $Æ$.}

\section{Roccus labrax L. (=Labrax lupus Cuv.)}

One specimen of a larval bass $6 \mathrm{~mm}$. long was obtained in Haul IX. (1), a midwater haul made in the west part of Bigbury Bay on May 15th, 1914. It is well represented by Raffaele's figure (1888 Tav. IV. Fig. 2), which is reproduced by Ehrenbaum in Nordisches Plankton (1905) as Fig. 7.d.

\section{LABRIDÆ.}

Labrus bergylta Asc. Labrus mixtus L. Ctenolabrus rupestris L.

Young stages of wrasse belonging to three different species occur in the material, but there is some slight doubt as to their correct specific determination. The most numerous of the forms is the one in which the body and the greater part of the tail is covered with many black stellate chromatophores, which, however, cease more or less abruptly behind the anal fin, leaving the hinder end of the tail unpigmented. This form has been figured by Danois (1913, p. 155) and there seems no reason to doubt that he has identified it correctly as $L$. bergylta. Holt's figure (1899, Pl. V. Fig. 49) is probably the same species, Ehrenbaum $(\mathbf{1 9 0 5}$, p. 7$)$ having already pointed out that it certainly is not Ctenolabrus rupestris as Holt has named it. The just hatched larva of $L$. bergylta was described by Matthews (188\%), and it is not improbable that the larva described by Hefford (1910, Pl. I. Figs. 8 and 8a) as L. mixtus also belongs here. In the present records, as well as in those by Clark (1914), all the specimens in which the body is deeply pigmented, but the hinder portion of the tail is quite free from pigment, have been regarded as Labrus bergylta.

A second form is Ctenolabrus rupestris. This is well figured by Ehrenbaum (1905, p. 8). The body is free from pigment excepting for a large 
post-anal black chromatophore on the body at the hinder end of the anal fin, and one or two chromatophores at the root of the caudal fin. I see no reason to question Ehrenbaum's identification, which is also accepted by Clark.

The third form, of which I give an illustration in Fig. 1, kindly made for me by Mr. E. Ford, has occurred not infrequently in the 1914 material. The distribution of the chromatophores is very constant and characteristic. On the dorsal edge of the body, at the base of the dorsal fin, there are on each side five large black chromatophores which remain in specimens preserved in formalin. One of these, the smallest, lies beneath the anterior end of the dorsal fin, followed by two large ones near the middle of the fin, and finally a pair close together near its hinder end. On the post-anal, ventral edge of the body there is a large chromatophore a little way behind the anus, and two more near the posterior end of the anal fin. A single black chromatophore can generally be seen at the

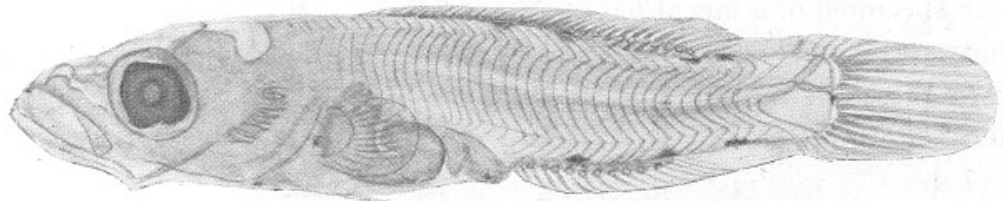

FIg. 1.-Labrus mixtus L. Length 10 mm. July 2nd, 1914.

base of the caudal fin. In the anterior part of the fish there are two or three large chromatophores on the top of the head, a row of small ones. on the mandible, two or three on the ventral edge of the abdomen, and one fairly large one immediately in front of the anus. A line of pigment extends along the dorsal side of the abdominal cavity, extending nearly to the anus. The number of vertebræ is 38 or 39 , rays of dorsal fin 30 or 31, of anal fin 14 or 15. These numerical characters agree completely with those given by Day for Labrus mixtus, and amongst the British Labridæ the only other species in which the number of vertebræ is so high is Labrus bergylta, the young stage of which seems to be satisfactorily known. I have little hesitation therefore in regarding Labrus mixtus as the proper name to give to the form we are considering. If that be so the larva described by Hefford $(\mathbf{1 9 1 0})$ is probably $L$. bergylta and not $L$. mixtus as he was inclined to think.

Post-larval stages of Labrus bergylta are most numerous in June and July, a few were taken in May and August, whilst in September they practically disappear from the young-fish trawl material. Ctenolabrus rupestris was most abundant in July. In 1914, the only year for which the species is recorded, Labrus mixtus was distinctly earlier in appearance than $C$. rupestris and was most abundant in June. 


\section{TABLE XVI.}

ReCord of Labrus SP.

\begin{tabular}{|c|c|c|c|c|c|c|c|c|}
\hline \multirow{3}{*}{$\begin{array}{l}\text { No. of haul. } \\
\text { IX.(1) }\end{array}$} & \multirow{3}{*}{$\begin{array}{l}\text { Date. } \\
\text { 15.v.14 }\end{array}$} & \multirow{3}{*}{$\begin{array}{l}\text { Depth. } \\
\text { M. }\end{array}$} & \multicolumn{2}{|c|}{ Labrus bergylta. } & \multicolumn{2}{|c|}{ Labrus mixtus. } & \multirow{2}{*}{\multicolumn{2}{|c|}{$\begin{array}{c}\text { Ctenolabrus } \\
\text { rupestris. } \\
\text { No. Size in mm. }\end{array}$}} \\
\hline & & & No. & Size in mm. & No. & Size in $\mathrm{mm}$ & & \\
\hline & & & $t$ & $5 \cdot 8-7 \cdot 3$ & - & - & - & - \\
\hline $\mathrm{x}$. & 19.v.14 & M. & 1 & $6 \cdot 5$ & - & - & - & - \\
\hline XII. & , & S. & - & - & 1 & $6 \cdot 6$ & - & - \\
\hline XIII. & , & M. & 1 & 6 & - & - & - & - \\
\hline XIV. & 25.v.14 & M. & 3 & $5 \cdot 6-6 \cdot 3$ & 2 & $7,7 \cdot 2$ & - & - \\
\hline XV. & ," & S. & 4 & $5 \cdot 2-6 \cdot 5$ & - & - & - & - \\
\hline $\mathrm{XVI}$. & , & S. & - & - & 1 & $8 \cdot 3$ & - & - \\
\hline XVII. & 3.vi.14 & B. & 13 & $5 \cdot 3-7 \cdot 5$ & 1 & $6 \cdot 5$ & - & - \\
\hline XVIII. & $"$ & B. & 6 & $6-7$ & - & - & - & - \\
\hline XIX. & ," & M. & 1 & $6 \cdot 5$ & - & - & - & - \\
\hline $\mathrm{XX}$. & 10.vi.14 & S.-M. & -- & - & 2 & $8-8 \cdot 5$ & - & - \\
\hline XXII. & 11.vi.14 & M. -B. & - & - & 1 & $9 \cdot 2$ & - & \\
\hline XXIII. & , & B. & - & - & 1 & 8.5 & - & - \\
\hline XXIV. & 16.vi.14 & B. & I & $5 \cdot 5$ & - & - & - & - \\
\hline $\mathrm{XXV}$. & , & B. & 1 & 5.5 & 1 & 6 & - & - \\
\hline XXVI. & , & B. & 1 & 6 & 2 & $6 \cdot 7-8$ & - & - \\
\hline XXVII. & , & M. & 2 & $6-7 \cdot 5$ & - & - & - & - \\
\hline XXIX. & 17.vi.14 & B. & 3 & $6 \cdot 3-7$ & - & - & - & - \\
\hline $\mathrm{x} \times \mathrm{x}$. &, & M. & 1 & $6 \cdot 5$ & 1 & $6 \cdot 5$ & - & - \\
\hline XXXIV. & 19.vi.14 & M. & 1 & $7 \cdot 4$ & - & - & - & - \\
\hline XXXVI. & 24.vi.14 & B. & - & - & 1 & 7 & 一 & - \\
\hline XXXVII. & , & B. & - & - & - & - & 1 & 6 \\
\hline XXXVIII. & ", & M. & - & - & - & - & 2 & $7 \cdot 3-8$ \\
\hline XLIII. & 29.vi.14 & B. & - & - & - & - & 1 & $8 \cdot 5$ \\
\hline XLVI. & 2.vii.14 & S. & 1 & $8 \cdot 3$ & 2 & $9-10$ & 1 & 9 \\
\hline XLVII. & ,, & S. & - & - & 2 & $6 \cdot 2-10$ & - & - \\
\hline XLVIII. & , & M. & 1 & $5 \cdot 7$ & - & - & - & - \\
\hline XLIX. & $"$ & M.-B. & 2 & $4 \cdot 5-5 \cdot 7$ & 1 & $8 \cdot 5$ & - & - \\
\hline $\mathrm{L}$. & 6.vii.14 & B. & 2 & $5 \cdot 5-6 \cdot 5$ & - & - & - & - \\
\hline LI. &, & B. & 11 & $4 \cdot 2-5 \cdot 6$ & - & - & - & - \\
\hline LII. & , & M. & 1 & $5 \cdot 3$ & - & - & - & - \\
\hline LIV. & 9.vii.14 & S. & 10 & $5 \cdot 7-6 \cdot 5$ & - & - & - & - \\
\hline LV. & ,, & M. & 12 & $4-5 \cdot 7$ & - & - & - & - \\
\hline LVI. & , & B. & 1 & 5 ca. & - & - & - & - \\
\hline LIX. & 15.vii. 14 & M. & 2 & $7-8$ & - & - & - & - \\
\hline LXI. & 16.vii.14 & B. & 1 & 7 & - & - & - & - \\
\hline LXII. & ,, & B. & 1 & 7 & - & - & - & - \\
\hline LXIII. & 22.vii. 14 & B. & 1 & $6 \cdot 6$ & - & - & - & - \\
\hline LXIV. & , & B. & 1 & 8 & - & - & - & - \\
\hline LXVIII. & , & B. & - & - & 2 & $7-7 \cdot 7$ & - & - \\
\hline LXIX. & , & S. & - & - & - & - & 1 & 8 \\
\hline LXXIII. & 29.vii.14 & M. & 1 & 6 & - & - & 1 & $8 \cdot 6$ \\
\hline LXXIV. & ,, & M. & - & - & - & - & 1 & $9 \cdot 5$ \\
\hline LXXV. & , & B. & - & - & - & - & 1 & $9 \cdot 6$ \\
\hline LXXX. & , & M. & 1 & 8 & - & - & 1 & 8.5 \\
\hline LXXXV. & 12.viii.14 & M. & 1 & $7 \cdot 5$ & - & - & - & - \\
\hline LXXXVI. & 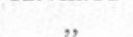 & B.-M. & 3 & $9 \cdot 5-10$ & - & - & 1 & 9 \\
\hline
\end{tabular}




\section{TABLE XVII.}

\section{LABRUS BERGYLTA.}

\begin{tabular}{|c|c|c|c|c|c|c|}
\hline Month. & & $\begin{array}{c}\text { Total number } \\
\text { of hauls } \\
1906-1914 .\end{array}$ & $\begin{array}{l}\text { Number of } \\
\text { hauls in } \\
\text { which the } \\
\text { species } \\
\text { occurs. }\end{array}$ & $\begin{array}{l}\text { Number } \\
\text { of } \\
\text { specimens. }\end{array}$ & Size in $\mathrm{mm}$. & $\begin{array}{l}\text { Average } \\
\text { number } \\
\text { per haul. }\end{array}$ \\
\hline May & . & 30 & 8 & 26 & $4 \cdot 5-7 \cdot 5$ & $0 \cdot 87$ \\
\hline June & & . 106 & 42 & 240 & $3 \cdot 25-24$ & $2 \cdot 2$ \\
\hline July & . & 94 & 49 & 348 & $3-20$ & $3 \cdot 7$ \\
\hline August & . & 75 & 19 & 29 & $3-10$ & $0 \cdot 38$ \\
\hline September & . & 85 & 1 & 1 & $4 \cdot 5$ & $0 \cdot 01$ \\
\hline
\end{tabular}

\section{TABLE XVIII}

\section{LABRUS MIXTUS.}

(1914 only.)

Number of

\begin{tabular}{|c|c|c|c|c|c|c|c|}
\hline Month. & & & $\begin{array}{l}\text { Total number } \\
\text { of hauls } \\
1914 \text { only. }\end{array}$ & $\begin{array}{l}\text { hauls in } \\
\text { which the } \\
\text { species } \\
\text { occurs. }\end{array}$ & $\begin{array}{l}\text { Number } \\
\text { of } \\
\text { specimens. }\end{array}$ & Size in $\mathrm{mm}$. & $\begin{array}{l}\text { Average } \\
\text { number } \\
\text { per haul. }\end{array}$ \\
\hline May. & . & . & 13 & 3 & 4 & $6 \cdot 6-8 \cdot 3$ & $0 \cdot 31$ \\
\hline June. & - & 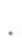 & 28 & 8 & 10 & $6 \cdot 5-9 \cdot 2$ & $0 \cdot 36$ \\
\hline July . & . & - & 38 & 3 & 7 & $7-10$ & 0.18 \\
\hline
\end{tabular}

\section{TABLE XIX.}

Ctenolabrus RUpestris.

Month.

Number of

\begin{tabular}{|c|c|c|}
\hline $\begin{array}{l}\text { ber } \\
4 .\end{array}$ & $\begin{array}{l}\text { Number of } \\
\text { hauls in } \\
\text { which the } \\
\text { species }\end{array}$ & $\begin{array}{l}\text { Number } \\
\text { of } \\
\text { specimens. }\end{array}$ \\
\hline
\end{tabular}

$\begin{array}{lllllll}\text { June . . } & . & 106 & 14 & 39 & 3.8-9 \cdot 8 & 0 \cdot 37\end{array}$

$\begin{array}{lllllll}\text { July . . } & 94 & 30 & 131 & 4-10 & 1 \cdot 4\end{array}$

$\begin{array}{lllllll}\text { August } & . & 75 & 8 & 13 & 5 \cdot 5-9 & 0 \cdot 17\end{array}$

\section{CARANGID E.}

\section{Caran $x$ trachurus $\mathrm{L}$.}

Only one specimen of the scad or horse mackerel is recorded amongst the 1914 material. This was $23.5 \mathrm{~mm}$. long, with most of the adult characters developed, and was taken in Haul LXXXVII. at midwater off Penlee Point on September 4th. The previous records given by Clark (1914, p. 348) are all for July, August and September. 


\section{SCOMBRIDA.}

Scomber scomber L.

Perhaps the most interesting feature in the material collected with the young-fish trawl in 1914 is the abundance of young stages of the mackerel, which were far more numerous than in any of the previous years for which records are available, though a number of specimens were taken by Hefford (see Clark, 1914, p. 349) in June, 1906, and June,

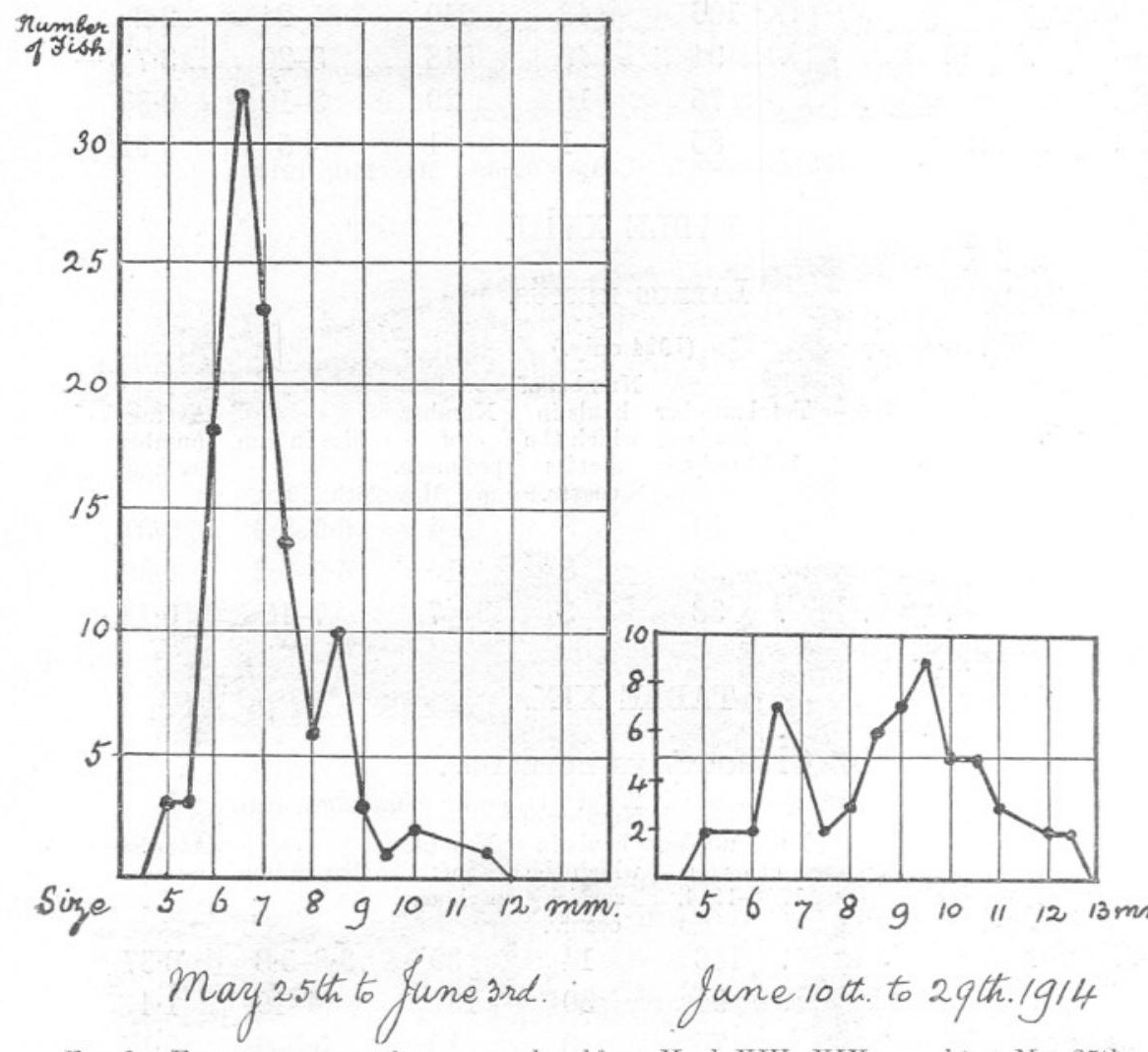

FIG. 2.-Frequency curve of young mackerel from Hauls XIV.-XIX., caught on May 25th and June $3 \mathrm{rd}, 1914$.

Fig. 3.-Frequency curve of young mackerel from Hauls XX.-XLV., caught June 10th to $29 \mathrm{th}, 1914$.

1908. These young stages were first taken on May 25th, when 22, 29 and 32 specimens were captured respectively in three successive hauls. The numkers were still considerable in the hauls on June 3rd. After that date they became less, but the young fish remained in the catches throughout June, whilst isolated specimens were captured in July.

The individual fishes were measured, and the results to the nearest 
$.5 \mathrm{~mm}$. are recorded in Table XX. Figs. 2 and 3 show in graphic form the length frequencies at each successive half-millimetre for two groups of hauls, the first group comprising XIV.-XIX., taken on May 25th and June 3rd, the second group comprising 16 hauls in which specimens occurred from Haul XX. to Haul XLV., taken between June 10th and 29th. The first group (Fig. 2) shows a definite mode at $6.5 \mathrm{~mm}$. and the

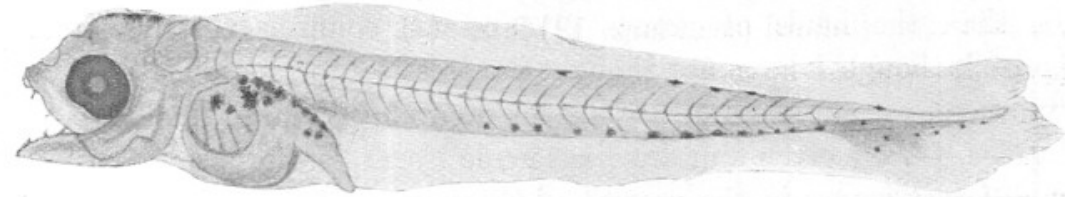

FrG. 4.-Scomber scomber L. Length $6 \mathrm{~mm}$. May 25th, 1914.

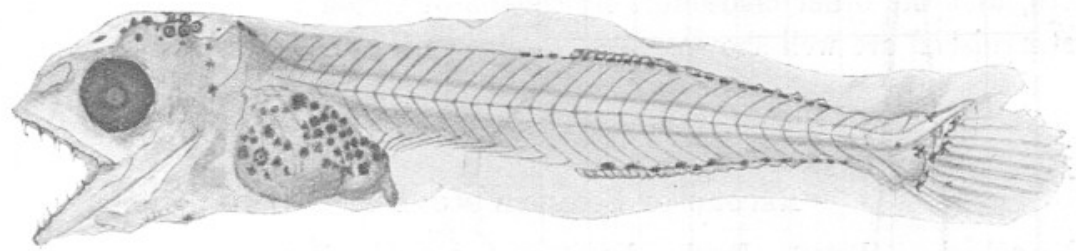

FIc. 5.-Scomber scomber L. Length $9 \mathrm{~mm}$. May $25 \mathrm{th}, 1914$.

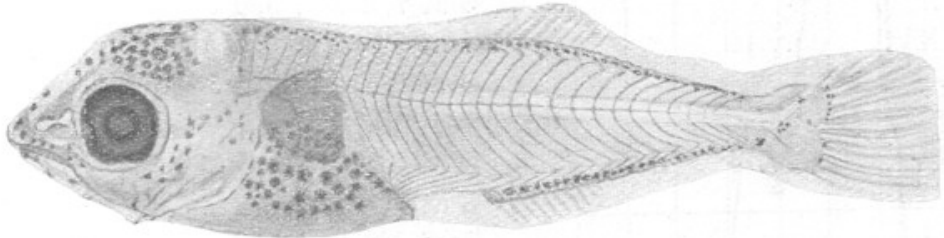

Fig. 6.-Scomber scomber L. Length 11.5 mm. May 25th, 1914.

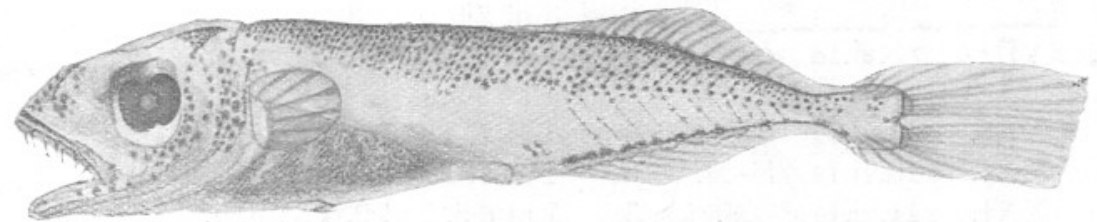

Fig. 7.-Scomber scomber L. Length $16 \mathrm{~mm}$. ca. July 22 nd, 1914.

arithmetic mean is $7 \cdot 15 \mathrm{~mm}$. The second group (Fig. 3) has two modes, one at $6.5 \mathrm{~mm}$. and another at $9.5 \mathrm{~mm}$., whilst the arithmetic mean is $8.8 \mathrm{~mm}$. It is probable that the mode at 9.5 in the second group (Fig. 3) is due to the group of fish found in the earlier hauls and represented in Fig. 2, which then showed a mode at $6.5 \mathrm{~mm}$. This would indicate a growth of $3 \mathrm{~mm}$. in three weeks. If this interpretation be correct then the other mode in Fig. 3, that at $6.5 \mathrm{~mm}$., would be most easily explained 
as being due to the offspring of a second shoal of spawning fish appearing some three weeks later than the one whose offspring are represented in Fig. 2. A more detailed analysis of the figures by taking five groups of hauls instead of two, namely, (1) XIV., XV., XVI., (2) XVII., XVIII., XIX., (3) XX., XXI., XXII., XXIII., (4) XXIV.-XXXVIII., (5) XLIII., XLIV., XLV., and noting that the fifth group comprises hauls taken more to the eastward, that is in the direction of the general Channel drift, than the hauls of groups (1) and (2) confirms the view just expressed, though I have not thought it necessary to reproduce the five curves here, the numbers of fish in each group being rather small.

In Figs. 4-7 are given four drawings made by Mr. E. Ford, representing four different stages in the growth of these young mackerel. In these drawings the characteristic distribution of the black pigment, the larval teeth, and the other characters by means of which the species can be distinguished are well shown.

\section{TABLE XX.}

Record of Scomber scomber.*

\begin{tabular}{|c|c|c|c|c|}
\hline No. of haul. & Date. & Depth. & No. & Sizes in $\mathrm{mm}$. \\
\hline XIV. & 25.v.14 & M. & 22 & $\begin{array}{l}2 \text { at } 5,1 \text { at } 5 \cdot 5,7 \text { at } 6,6 \text { at } 6 \cdot 5, \\
3 \text { at } 7,1 \text { at } 7 \cdot 5,1 \text { at } 8,1 \text { at } 8 \cdot 5 .\end{array}$ \\
\hline $\mathrm{XV}$. & 25.v.14 & S. & 29 & $\begin{array}{l}1 \text { at } 5 \cdot 5,2 \text { at } 6,8 \text { at } 6 \cdot 5,5 \text { at } 7, \\
4 \text { at } 7 \cdot 5,2 \text { at } 8,4 \text { at } 8 \cdot 5,2 \text { at } 9, \\
1 \text { at } 10 .\end{array}$ \\
\hline XVI. & 25.v.14 & S. & 32 & $\begin{array}{l}1 \text { at } 5,7 \text { at } 6,8 \text { at } 6 \cdot 5,5 \text { at } 7, \\
3 \text { at } 7 \cdot 5,1 \text { at } 8,4 \text { at } 8 \cdot 5,1 \text { at } 9, \\
1 \text { at } 10,1 \text { at } 11 \cdot 5 \text {. }\end{array}$ \\
\hline XVII. & 3.vi.14 & B. & 21 & $\begin{array}{l}1 \text { at } 5 \cdot 5,1 \text { at } 6,8 \text { at } 6 \cdot 5,6 \text { at } 7, \\
3 \text { at } 7 \cdot 5,2 \text { at } 8 .\end{array}$ \\
\hline XVIII. & 3.vi.14 & B. & 10 & $\begin{array}{l}1 \text { at } 6,3 \text { at } 6 \cdot 5,3 \text { at } 7,2 \text { at } 75 \text {, } \\
1 \text { at } 9 \cdot 5 \text {. }\end{array}$ \\
\hline XIX. & 3.vi.14 & M. & 3 & 1 at 7,1 at $7 \cdot 5,1$ at $8 \cdot 5$. \\
\hline $\mathrm{XX}$. & 10.vi.14 & S.-M. & 3 & 1 at 7,1 at 8,1 at 12.5 . \\
\hline XXI. & 11.vi.14 & M. & 3 & 1 at $8.5,1$ at 9,1 at $10 \cdot 5$. \\
\hline XXII. & 11.vi.14 & M.-B. & 4 & 1 at $7 \cdot 5,2$ at 11,1 at 12 . \\
\hline XXIII. & 11.vi.14 & B. & 4 & 1 at 9,2 at $10 \cdot 5,1$ at 11 . \\
\hline XXIV. & 16.vi.14 & B. & 1 & 1 at 6.5 \\
\hline XXVI. & 16.vi.14 & B. & 2 & 1 at $8 \cdot 5,1$ at $9 \cdot 5$ \\
\hline XXVII. & 16.vi.14 & M. & 7 & $\begin{array}{l}1 \text { at } 5,1 \text { at } 6,2 \text { at } 9,2 \text { at } 9 \cdot 5, \\
1 \text { at } 10 .\end{array}$ \\
\hline XXXI. & 17.vi.14 & M. & 2 & 1 at 5,1 at 8.5 . \\
\hline XXXII. & 17.vi.14 & S. & 2 & 1 at 8,1 at 9 . \\
\hline
\end{tabular}

\footnotetext{
* Measurements to the nearest $5 \mathrm{~mm}$.
} 


\section{TABLE XX. (continued).}

\begin{tabular}{rrrrl} 
No. of haul. & Date. & Depth. & No. & \multicolumn{1}{c}{ Sizes in mm. } \\
XXXIII. & $19 . v i .14$ & M. & 1 & 1 at $12 \cdot 5$. \\
XXXIV. & $19 . v i .14$ & M. & 1 & 1 at $6 \cdot 5$. \\
XXXVI. & $24 . v i .14$ & B. & 1 & 1 at 7. \\
XXXVII. & $24 . v i .14$ & B. & 1 & 1 at 7. \\
XXXVIII. & $24 . v i .14$ & M. & 11 & $\begin{array}{l}1 \text { at } 6,4 \text { at } 6 \cdot 5,2 \text { at } 7,1 \text { at } 7 \cdot 5 \text {, } \\
\end{array}$ \\
& & & 1 at 8,1 at $8 \cdot 5,1$ at $9 \cdot 5$. \\
XLIII. & $29 . v i .14$ & B. & 2 & 1 at $8.5,1$ at $9 \cdot 5$. \\
XLIV. & $29 . v i .14$ & M. & 3 & 1 at $6 \cdot 5,2$ at $9 \cdot 5$. \\
XLV. & $29 . v i .14$ & S. & 12 & 1 at $8 \cdot 5,2$ at 9,2 at $9.5,4$ at 10 , \\
& & & & 2 at $10 \cdot 5,1$ at 12. \\
LX. & $15 . v i i .14$ & M. & 1 & 1 at $9 \cdot 5$. \\
LXVIII. & $22 . v i i .14$ & B. & 1 & 1 at 16. \\
LXIX. & $22 . v i i .14$ & S. & 1 & 1 at $8 \cdot 5$.
\end{tabular}

ZEID $A$.

Zeus faber $\mathrm{L}$.

One specimen only, $12 \mathrm{~mm}$. long, was taken, this being found in Haul LXXXIV., a bottom haul made on July 29th, 1914. For 1913 Clark (1914) has recorded a number of specimens in August and September.

\section{PLEURONECTID $Æ$.}

\section{Pleuronectes limanda $\mathrm{L}$.}

Post-larval dates are exceptionally well represented in the 1914 material. Already at the end of April when the collection began 29 and 37 specimens were obtained in one haul. The maximum abundance was reached in May, and in three hauls taken off the Eddystone on May 25th, 290, 276, and 508 individuals were captured. It is worth noting that these three hauls were taken during the dark hours of the night, between 10.25 p.m. and midnight. During June the numbers obtained fell off rapidly and after the 2nd July no more specimens were obtained. During June also the most prolific hauls were made at night. The details of the captures for 1914 are shown in Table XXI., whilst Table XXII. gives monthly summaries of the hauls made during the period 1906-14.

\section{Pleuronectes microcephalus Donov.}

Although no young merry-soles were taken until May 15th the captures reached a maximum before the end of that month, falling off during 
June and July, when chiefly the larger sizes were taken. The figures for 1914 are given in Table XXI., and the monthly summaries for 1906-14 in Table XXIII.

The species is more abundant in hauls taken beyond the 20 -fathom line. In Table XXIII. this is shown by the figures given for the month of May. The average number of individuals per haul for all the hauls is $6 \cdot 6$, whilst the average for the hauls at and beyond the 20 -fathom line is $12 \cdot 2$.

\section{TABLE XXI.}

Record of Pleuronectes sp.

\begin{tabular}{|c|c|c|c|c|c|c|}
\hline \multirow{2}{*}{$\begin{array}{l}\text { No. of } \\
\text { Haul. }\end{array}$} & \multirow{3}{*}{$\begin{array}{c}\text { Date. } \\
\text { 29.iv.14 }\end{array}$} & \multirow{2}{*}{ Depth. } & \multicolumn{2}{|c|}{ P. limanda. } & \multicolumn{2}{|c|}{ P, microcephalus. } \\
\hline & & & No. & Size in $\mathrm{mm}$. & No. & Size in mm. \\
\hline V. & & B. & 36 & $5 \cdot 5-11 \cdot 5$ & - & - \\
\hline VI. & , & M. & 29 & $4 \cdot 5-9 \cdot 2$ & - & - \\
\hline VII. & ", & S. & 6 & $5 \cdot 5-10 \cdot 5$ & - & - \\
\hline VIII.(2) & , & M. & 3 & $6 \cdot 2-8 \cdot 5$ & - & - \\
\hline IX.(5) & 15.v. 14 & B. & 23 & $5-12 \cdot 6$ & 3 & $9 \cdot 5-11 \cdot 2$ \\
\hline $\mathrm{X}$. & 19.v.14 & M. & 5 & $8 \cdot 5-14 \cdot 3$ & 37 & $5-11$ \\
\hline XI. & $"$ & S. & 8 & $9-13 \cdot 8$ & 22 & $6 \cdot 5-10 \cdot 5$ \\
\hline XII. & , & S. & 35 & $4-14 \cdot 8$ & 21 & $6 \cdot 8-10 \cdot 6$ \\
\hline XIII. & , & M. & 70 & $4 \cdot 7-12 \cdot 0$ & 55 & $6-15$ \\
\hline XIII.a & 22.v.14 & & 46 & $6 \cdot 5-13$ & - & - \\
\hline XIV. & 25.v.14 & M. & 290 & $5 \cdot 7-15$ & 25 & $7-14 \cdot 7$ \\
\hline $\mathrm{XV}$. & ", & S. & 276 & $5 \cdot 5-12 \cdot 5$ & 7 & $9 \cdot 6-13 \cdot 5$ \\
\hline XVI. & , & S. & 508 & $5-12 \cdot 6$ & 12 & $7 \cdot 5-14 \cdot 5$ \\
\hline XVII. & 3.vi.14 & B. & 45 & $6 \cdot 5-11 \cdot 5$ & 5 & $7-9$ \\
\hline XVIII. & ", & B. & 9 & $6-8$ & 8 & $5 \cdot 2-7 \cdot 5$ \\
\hline XIX. & , & M. & 4 & $6 \cdot 7-8$ & 1 & 6 \\
\hline XX. & 10.vi.14 & S.-M. & 22 & $8 \cdot 2-14 \cdot 5$ & 3 & $9 \cdot 5-16$ \\
\hline XXI. & 11.vi.14 & M. & 14 & $8-14 \cdot 2$ & 3 & $10 \cdot 6-14$ \\
\hline XXII. & , & M.-B. & 31 & $8 \cdot 5-17$ & 11 & $10-15 \cdot 6$ \\
\hline XXIII. & ", & B. & 32 & $9-15 \cdot 6$ & 22 & 9-14 \\
\hline XXVI. & 16.vi.14 & B. & 3 & $10 \cdot 5-11 \cdot 6$ & - & - \\
\hline XXVII. & , & M. & 1 & $10 \cdot 5$ & - & - \\
\hline XXVIII. & ; & B. & 1 & $12 \cdot 5$ & - & - \\
\hline XXXI. & 17.vi.14 & M. & 2 & $8 \cdot 7-11$ & - & - \\
\hline XXXII. & , & S. & - & - & 1 & 7 \\
\hline XXXVII. & 24.vi.14 & B. & 1 & $10 \cdot 2$ & 3 & 8-12 \\
\hline XLIII. & 29.vi.14 & B. & 1 & $10 \cdot 5$ & - & - \\
\hline XLVI. & 2.vii.14 & S. & 8 & $6 \cdot 5-17 \cdot 3$ & 2 & $12 \cdot 4-12 \cdot 7$ \\
\hline XLVII. & , & S. & 1 & 8.5 & 3 & $11 \cdot 5-15 \cdot 2$ \\
\hline
\end{tabular}


TABLE XXI. (continued).

\begin{tabular}{|c|c|c|c|c|c|c|}
\hline No of & & & \multicolumn{2}{|c|}{ P. limanda. } & \multicolumn{2}{|c|}{ P. microcephalus. } \\
\hline $\begin{array}{c}\text { Haul. } \\
\text { XLVIII. }\end{array}$ & $\begin{array}{l}\text { Date. } \\
\text { 2.vii.14 }\end{array}$ & $\begin{array}{l}\text { Depth. } \\
\text { M. }\end{array}$ & $\begin{array}{r}\text { No. } \\
3\end{array}$ & $\begin{array}{l}\text { Size in mm. } \\
15 \cdot 5-16\end{array}$ & $\begin{array}{r}\text { No. } \\
3\end{array}$ & $\begin{array}{r}\text { Size in } \mathrm{mm} . \\
9-18.5\end{array}$ \\
\hline XLIX. & , & M.-B. & 2 & $15 \cdot 5-16 \cdot 6$ & - & - \\
\hline LVI. & 9.vii.14 & B. & - & - & 2 & $9 \cdot 2-11 \cdot 5$ \\
\hline LVII. & "2 & B. & - & - & 2 & $9-9 \cdot 5$ \\
\hline LXVIII. & 22.vii.1 & B. & 一 & - & 1 & 8 \\
\hline XXVIII. & 29.vii.14 & M. & - & - & 1 & 8 \\
\hline
\end{tabular}

Pleuronectes flesus L. occurred in the following hauls:-V. 1 spec. $7 \mathrm{~mm}$., VII. 3 specs. $6.5-8.5 \mathrm{~mm}$., VIII. (1) 2 specs. $8-8.5 \mathrm{~mm}$., VIII. (2) 2 specs. $8-8.5 \mathrm{~mm}$., IX. (1) 1 spec. $9 \mathrm{~mm}$, IX. (2) 33 specs, $5 \cdot 5-10.5 \mathrm{~mm}$.

\section{TABLE XXII.}

\section{Pleuronectes limanda.}

Month.

Number of

Totalnumber hanls in Number Average 1906-1914. whecies specimens.

\begin{tabular}{|c|c|c|c|c|c|c|c|}
\hline April & . & • & 7 & 5 & 86 & $4 \cdot 5-11 \cdot 5$ & $12 \cdot 3$ \\
\hline May. & . & . & 30 & 20 & 1371 & $4-15$ & $45 \cdot 7$ \\
\hline June. & . & . & 106 & 28 & 199 & $1 \cdot 59-17$ & 1.9 \\
\hline July . & . & . & 94 & 5 & 17 & $6 \cdot 5-42$ & $0 \cdot 18$ \\
\hline
\end{tabular}

\section{TABLE XXIII.}

\section{Pleuronectes mitrocephalus.}

Month.

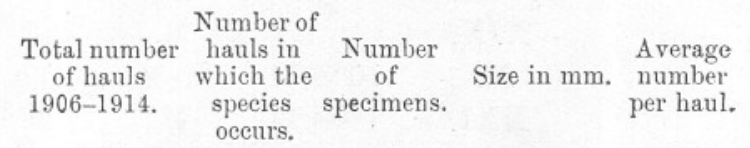

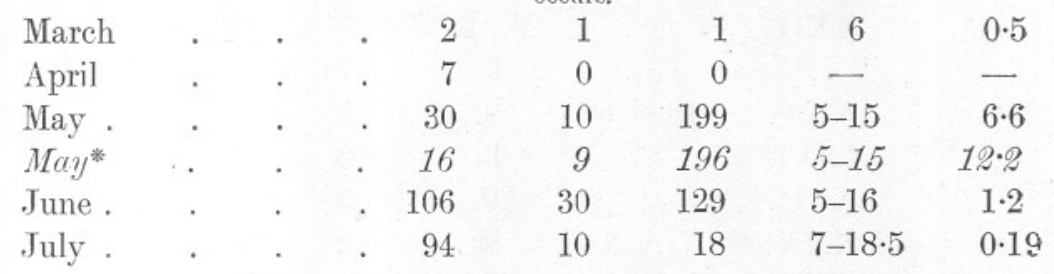

\footnotetext{
* Hauls where total depth of water is 2 J fathoms and over.
} 


\section{PLEURONECTID瓜.}

Sub.-fam. Вотнімж.

Arnoglossus sp.

The records for 1914 are given in Table XXIV. By far the greater number of specimens taken belong certainly to the species Arnoglossus laterna. There were a certain number of doubtful cases, but in no instance was I able to feel sure that the specimen should be attributed to A. Thori or A. imperiatis.

The monthly summaries for the whole period 1906-14 given in Table $\mathrm{XXV}$. show a maximum frequency in September with an average of $8 \cdot 3$ per haul. The average for August $6 \cdot 8$ is also high. It may be noted, however, that the post-larval Arnoglossus seems to have been more abundant in June, 1914, than it was in that month of previous years, the average for the month being 8.4 in 1914, whilst for the whole period it is only $2 \cdot 3$.

\section{TABLE XXIV.}

Record of Arnoglossus sp.

\begin{tabular}{|c|c|c|c|c|}
\hline $\begin{array}{l}\text { No. of haul. } \\
\text { XI. }\end{array}$ & $\begin{array}{c}\text { Date. } \\
\text { 19.v.14 }\end{array}$ & $\begin{array}{l}\text { Depth. } \\
\text { S. }\end{array}$ & $\begin{array}{c}\text { No. } \\
1\end{array}$ & $\begin{array}{c}\text { Size in mm. } \\
5.5 \text { ca. }\end{array}$ \\
\hline XIII. & , & M. & 1 & $5 \cdot 6$ \\
\hline XIV. & 25.v.14 & M. & 5 & $5-8 \cdot 3$ \\
\hline $\mathrm{XV}$. & " & S. & 7 & $6 \cdot 5-8 \cdot 3$ \\
\hline XVI. & , & S. & 12 & $5 \cdot 6-7 \cdot 6$ \\
\hline XVII. & 3.vi.14 & B. & 11 & $5 \cdot 5-7 \cdot 5$ \\
\hline XVIII. & " & B. & 18 & $4-8$ \\
\hline XIX. & , & M. & 1 & $5 \cdot 2$ \\
\hline XX. & 10.vi.14 & S.-M. & 17 & $9 \cdot 5-11 \cdot 7$ \\
\hline XXI. & 11.vi.14 & M. & 28 & $6 \cdot 5-11 \cdot 2$ \\
\hline XXII. & , & M. - B. & 27 & $7-11$ \\
\hline XXIII. & , & B. & 47 & $7 \cdot 5-12 \cdot 3$ \\
\hline XXV. & 16.vi.14 & B. & 1 & 7 \\
\hline XXVI. & , & B. & 10 & $3 \cdot 5-7 \cdot 3$ \\
\hline XXVII. & , & M. & 3 & $6 \cdot 3-9$ \\
\hline XXX. & 17.vi.14 & M. & 2 & $6: 5$ \\
\hline XXXI. & ," & M. & 18 & $5 \cdot 5-10$ \\
\hline XXXII. & , & S. & 3 & 6-10 ca. \\
\hline XXXIV. & 19.vi.14 & M. & 5 & $6 \cdot 4-10 \cdot 8$ \\
\hline
\end{tabular}


TABLE XXIV. (continued).

\begin{tabular}{|c|c|c|c|c|}
\hline $\begin{array}{c}\text { No. of haul. } \\
\text { XXXV. }\end{array}$ & $\begin{array}{c}\text { Date. } \\
\text { 19.vi.14 }\end{array}$ & $\begin{array}{c}\text { Depth. } \\
\text { M. }\end{array}$ & No. & $\begin{array}{l}\text { Size in } \mathrm{mm} \text {. } \\
6 \cdot 5-12 \cdot 3\end{array}$ \\
\hline XXXVI. & 24.vi.14 & B. & 6 & $6 \cdot 5-14$ \\
\hline XXXVII. & , & B. & 1 & $10 \cdot 5$ \\
\hline XXXVIII. & " & M. & 10 & - \\
\hline XLII. & 29.vi.14 & B. & 2 & $9-14.5$ \\
\hline XLIII. & " & B. & 14 & $8 \cdot 5-18 \cdot 5$ \\
\hline XLIV. & , & M. & 5 & $5-17 \cdot 5$ \\
\hline XLV. & , & S. & 3 & $6 \cdot 5-9$ \\
\hline XLVI. & 2.vii.14 & S. & 4 & $8 \cdot 2-13$ \\
\hline XLVII. & ", & S. & 1 & $15 \cdot 5$ \\
\hline XLVIII. & , & M. & 4 & $11-18$ \\
\hline XLIX. & , & M. $-\mathrm{B}$. & 3 & $6 \cdot 5-15$ \\
\hline L. & 6.vii.14 & B. & 1 & $18 \cdot 3$ \\
\hline LI. & , & B. & 4 & $4 \cdot 5-18 \cdot 5$ \\
\hline LII. & , & M. & 1 & 17 \\
\hline LV. & 9.vii.14 & M. & 2 & $12 \cdot 5-16 \cdot 5$ \\
\hline LVI. & " & B. & 6 & $11-17 \cdot 5$ \\
\hline LVII. & " & B. & 1 & 13 \\
\hline LVIII. & , & M. & 1 & $19 \cdot 5$ \\
\hline LIX. & 15.vii.14 & M. & 29 & $13 \cdot 5-22$ \\
\hline LX. & , & M. & 11 & $13 \cdot 4-20 \cdot 3$ \\
\hline LXI. & 16.vii.14 & B. & 2 & $13-16$ \\
\hline LXII. & , & B. & 6. & $15-21 \mathrm{ca}$. \\
\hline LXIII. & 22.vii. 14 & B. & 1 & $7 \cdot 2$ \\
\hline LXVII. & , & M. & 7 & $7 \cdot 2-19 \cdot 5$ \\
\hline LXVIII. & ", & B. & 5 & $7-20 \cdot 5$ \\
\hline LXX. & , & M. & 2 & $18 \cdot 7-21 \cdot 2$ \\
\hline LXXIII. & 29.vii.14 & M. & 10 & $6 \cdot 3-20 \cdot 5$ \\
\hline LXXV. & , & B. & 4 & $8 \cdot 2-20 \cdot 5$ \\
\hline LXXVI. & ", & M. & 5 & $17-20 \cdot 5$ \\
\hline LXXVII. & , & B. & 1 & 20 \\
\hline LXXVIII. & , & M. & 14 & $10-23 \cdot 5$ \\
\hline LXXXIII. & " & B. & 3 & $9 \cdot 5-20 \cdot 5$ \\
\hline LXXXV. & 12.viii.14 & M. & 2 & $24 \cdot 5-25 \cdot 6$ \\
\hline
\end{tabular}




\section{TABLE XXV.}

Arnoglossus sp.

\begin{tabular}{|c|c|c|c|c|c|c|}
\hline Month. & & $\begin{array}{l}\text { Total number } \\
\text { of hauls } \\
1906-1914 .\end{array}$ & $\begin{array}{l}\text { Number of } \\
\text { hauls in } \\
\text { which the } \\
\text { species } \\
\text { occurs }\end{array}$ & $\begin{array}{l}\text { Number } \\
\text { of } \\
\text { specimens. }\end{array}$ & Size in mm. & $\begin{array}{l}\text { Average } \\
\text { number } \\
\text { per haul. }\end{array}$ \\
\hline May. & & 30 & 5 & 26 & $5-8 \cdot 3$ & $0 \cdot 87$ \\
\hline June . & & . 106 & 30 & 249 & $3 \cdot 5-18 \cdot 5$ & $2 \cdot 3$ \\
\hline [June, 1914 & & 28 & 22 & 235 & $3 \cdot 5-18 \cdot 5$ & $8 * 4]$ \\
\hline July . & & 94 & 41 & 232 & $3 \cdot 5-23 \cdot 5$ & $2 \cdot 5$ \\
\hline August & & 75 & 47 & 507 & $3-28 \cdot 5$ & $6 \cdot 8$ \\
\hline Septembe & & 85 & 62 & 708 & $4-31$ & $8 \cdot 3$ \\
\hline October & . & 14 & 2 & 2 & 7 & $0 \cdot 14$ \\
\hline
\end{tabular}

Sub-fam. RHомвINж.

Rhombus maximus Will. R. laevis Rond.

Seven specimens of $R$. laevis were taken in 1914 between May and August, and one specimen of $R$. maximus in July. These records support the conclusion reached by Clark that the spawning season of the brill is earlier than that of the turbot.

\section{TABLE XXVI.}

RECORD of Rhombus sp.

\begin{tabular}{|c|c|c|c|c|c|c|}
\hline \multirow{2}{*}{$\begin{array}{l}\text { No. of haul. } \\
\text { XIV. }\end{array}$} & \multirow[b]{2}{*}{$\begin{array}{c}\text { Date. } \\
\text { 25.v.14 }\end{array}$} & \multirow[b]{2}{*}{$\begin{array}{c}\text { Depth. } \\
\text { M. }\end{array}$} & \multicolumn{2}{|c|}{ R. maximus. } & \multicolumn{2}{|c|}{ R. laevis. } \\
\hline & & & No. & Size in $\mathrm{mm}$. & $\begin{array}{c}\text { No. } \\
2\end{array}$ & $\begin{array}{r}\text { Size in } \mathrm{mm} \text {. } \\
9 \cdot 8-11 \cdot 5\end{array}$ \\
\hline $\mathrm{XV}$. & 25.v.14 & S. & - & 一 & 2 & $6 \cdot 8,6 \cdot 8$ \\
\hline LXX. & 22.vii.14 & M. & - & - & 1 & $6 \cdot 2$ \\
\hline LXXVI. & 29.vii.14 & M. & 2 & $7 \cdot 7-8 \cdot 5$ & - & - \\
\hline LXXVIII. & 29.vii.14 & M. & - & - & 1 & 7 \\
\hline LXXXV. & 12. viii.14 & M. & - & 一 & 1 & 13 \\
\hline
\end{tabular}

Scophthalmus norvegicus Gthr.

The records for 1914 (Table XXVII.) give a distinct maximum of the post-larval stages in May. The numbers remain fairly large until June 11th, after which only a few specimens were taken. This would indicate that the maximum spawning season is a little earlier than Clark (1914) suggests, being probably in April. The hauls containing the largest number of individuals were made south of the Eddystone, where the depths were from 37-39 fathoms. The monthly summary for the period 1906-14 shows an average number of $14 \cdot 6$ individuals per haul for May, and of $5 \cdot 4$ for June (Table XXVIII.). 


\section{TABLE XXVII.}

ReCoRd of Scophthalmus nORvegicus.

\begin{tabular}{|c|c|c|c|c|}
\hline $\begin{array}{r}\text { No. of haul. } \\
\text { X. }\end{array}$ & $\begin{array}{c}\text { Date. } \\
\text { 19.v.14 }\end{array}$ & $\begin{array}{c}\text { Depth. } \\
\text { M. }\end{array}$ & $\begin{array}{l}\text { No. } \\
69\end{array}$ & $\begin{array}{c}\text { Size in mm. } \\
4 \cdot 2-11\end{array}$ \\
\hline XI. & , & S. & 44 & $4-12$ \\
\hline XII. & , & S. & 68 & $4 \cdot 5-12$ \\
\hline XIII. & ", & M. & 84 & $4-11 \cdot 7$ \\
\hline XIII.a & 22.v.14 & - & 2 & $6-6 \cdot 6$ \\
\hline XIV. & 25.v.14 & M. & 5 & $5 \cdot 5-10$ \\
\hline XV. & ", & S. & 1 & $9 \cdot 5$ \\
\hline XVI. & ", & S. & 6 & $6 \cdot 5-10 \cdot 5$ \\
\hline XVII. & 3.vi.14 & B. & 45 & $4 \cdot 0-8 \cdot 0$ \\
\hline XVIII. & " & B. & 31 & $4 \cdot 5-8$ \\
\hline XIX. & , & M. & 1 & 7 \\
\hline XX. & 10.vi.14 & S.-M. & 5 & $6-8$ \\
\hline XXI. & 11.vi.14 & M. & 11 & $5 \cdot 5-8 \cdot 5$ \\
\hline XXII. & , & M.-B. & 16 & $6-8 \cdot 7$ \\
\hline XXIII. & ", & B. & 27 & $6-8 \cdot 7$ \\
\hline XXVI. & 16.vi.14 & B. & 1 & $5 \cdot 5$ \\
\hline XXX. & 17.vi.14 & M. & 1 & 6 \\
\hline XLVI. & 2.vii.14 & S. & 1 & $9 \cdot 7$ \\
\hline LVI. & 9.vii. 14 & B. & 1 & $7 \cdot 3$ \\
\hline LIX. & 15.vii.14 & M. & 1 & 6 \\
\hline LXVIII. & 22.vii.14 & B. & 1 & $7 \cdot 2$ \\
\hline
\end{tabular}

\section{TABLE XXVIII.}

SCOPHTHaLMUS NORVEGICUS.

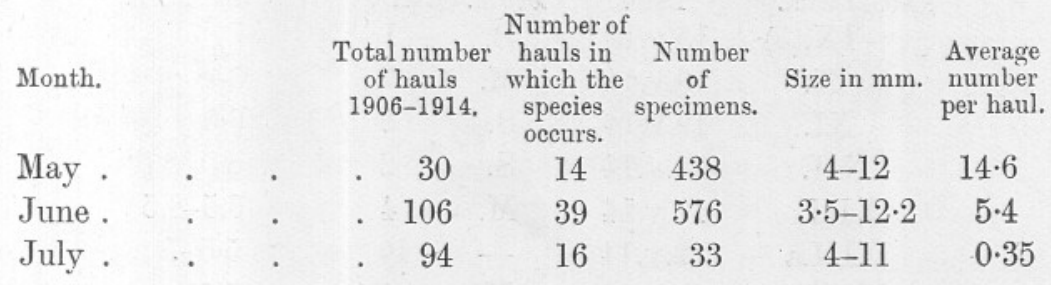

\section{Zeugopterus unimaculatus Bnp.}

Fourteen specimens of post-larvæ one-spotted topknots were taken in 1914. The only previous records are those of Clark, who found three specimens in June and July, 1913. The 1914 records are of specimens taken in May and the early part of June. The species is easily distinguished from the other topknots. 


\section{TABLE XXIX.}

Record of Zeugopterus unimaculatus Gthr.

$\begin{array}{rrccc}\text { No. of haul. } & \text { Date. } & \text { Depth. } & \text { No. } & \text { Size in mm. } \\ \text { XI. } & \text { 19.v.14 } & \text { S. } & 1 & 8 \\ \text { XIII. } & \text { 19.v.14 } & \text { M. } & 1 & 5 \cdot 5 \\ \text { XIV. } & \text { 25.v.14 } & \text { M. } & 1 & 6 \cdot 5 \\ \text { XV. } & 25 . v .14 & \text { S. } & 1 & 8 \cdot 7 \\ \text { XVI. } & 25 . v .14 & \text { S. } & 1 & 8 \\ \text { XVII. } & 3 . v i .14 & \text { B. } & 3 & 6-6 \cdot 5 \\ \text { XVIII. } & 3 . v i .14 & \text { B. } & 2 & 6-6 \cdot 2 \\ \text { XXI. } & \text { 11.vi.14 } & \text { M. } & 1 & 8 \cdot 6 \\ \text { XXII. } & \text { 11.vi.14 } & \text { M. } & 1 & 9 \cdot 3 \\ \text { XXIII. } & \text { 11.vi.14 } & \text { B. } & 2 & 8-9 \cdot 4\end{array}$

\section{Zeugopterus punctatus Blainv.}

In 1914 the post-larvæ were much more frequent in May than in June, indeed they practically disappeared after the beginning of the latter month. The maximum frequency for the whole period 1906-14 occurred in April, though the figure is based on too few hauls to be very reliable. It is clear, however, that the species must have its maximum spawning period in the early months of the year.

\section{TABLE XXX.}

Record of Zeugopterus punctatus Bl.

$\begin{array}{rrrrl}\text { No. of haul. } & \text { Date. } & \text { Depth. } & \text { No. } & \text { Size in mm. } \\ \text { IX.(5) } & \text { 15.v.14 } & \text { B. } & 1 & 7 \\ \text { X. } & \text { 19.v.14 } & \text { M. } & 7 & 5-8 \\ \text { XI. } & \text { 19.v.14 } & \text { S. } & 1 & 6 \cdot 5 \\ \text { XII. } & \text { 19.v.14 } & \text { S. } & 2 & 8 \cdot 5,8.5 \\ \text { XIII. } & \text { 19.v.14 } & \text { M. } & 4 & 6.5-8.5 \\ \text { XIII.a } & 22 . v .14 & - & 10 & 5 \cdot 5-7 \\ \text { XIV. } & 25 . v .14 & \text { M. } & 1 & 7 \cdot 5 \\ \text { XV. } & 25 . v .14 & \text { S. } & 1 & 8 \\ \text { XVI. } & 25 . v .14 & \text { S. } & 7 & 8 \cdot 5-10 \cdot 2 \\ \text { XVII. } & \text { 3.vi.14 } & \text { B. } & 2 & 6 \cdot 5-6 \cdot 7 \\ \text { XVIII. } & \text { 3.vi.14 } & \text { B. } & 1 & 7 \cdot 3 \\ \text { XIX. } & \text { 3.vi.14 } & \text { M. } & 1 & 6 \\ \text { XXII. } & 11 . v i .14 & \text { M. } & 1 & 7 \cdot 6\end{array}$




\section{TABLE XXXI.}

\section{Zeugopterus punctatus.}

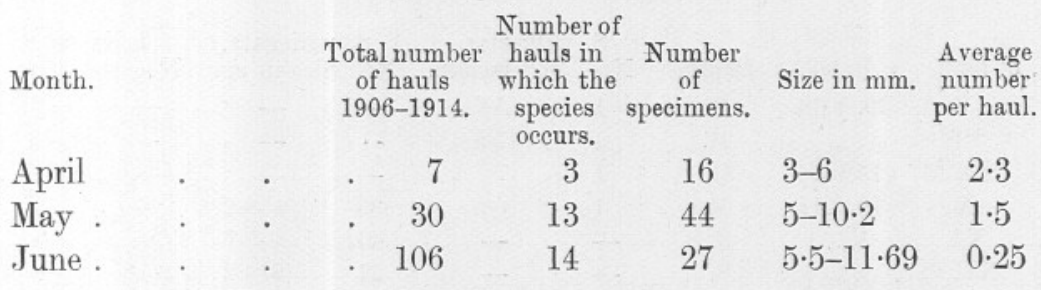

Sub-fam. SoleIN E.

Solea vulgaris Quens.

The majority of the specimens of post-larvæ of the common sole were taken in May. The number captured was, however, not large and was below that of the thickback sole (S. variegata).

\section{Solea variegata Don.}

These were taken in considerable numbers during May and a few were also present in June. The maximum number taken in one haul was 48 , in marked contrast to $S$. vulgaris, of which only one specimen occurred in a haul, except in two cases where there were 2 and 4 specimens.

\section{Solea lascaris Risso.}

Only two specimens were found in the 1914 material, taken on the 22nd July. Previous records made by Clark in 1913 are in July, August, and September.

\section{Solea lutea Risso.}

Not a single specimen of $S$. lutea was recognised in the 1914 material, although in 1913 Clark found a fair number in June, a month which is well represented in the 1914 hauls. 


\section{TABLE XXXII.}

\section{RECORD OF Solea.}

\begin{tabular}{|c|c|c|c|c|c|c|c|c|}
\hline haul. & Date & Denth & S. & $\begin{array}{l}\text { vulgaris. } \\
\text { Size in mm. }\end{array}$ & S. & $\begin{array}{l}\text { variegata. } \\
\text { Size in } \mathrm{mm} .\end{array}$ & S. & $\begin{array}{l}\text { ascaris. } \\
\text { ze in mn }\end{array}$ \\
\hline V. & 29.iv.14 & B. & 1 & $5 \cdot 7$ & - & - & - & - \\
\hline VI. & , & M. & 1 & $7 \cdot 5$ & - & - & - & - \\
\hline IX.(5) & 15.v.14 & B. & 1 & 7 & - & - & - & -. \\
\hline $\mathrm{x}$. & 19.v.14 & M. & 1 & $6 \cdot 9$ & 33 & $4-8 \cdot 2$ & - & - \\
\hline XI. & , & S. & - & - & 41 & $4-9 \cdot 5$ & - & - \\
\hline XII. & , & S. & - & - & 21 & $5 \cdot 5-9 \cdot 2$ & - & - \\
\hline XIII. & , & M. & - & - & 48 & $4 \cdot 5-10 \cdot 2$ & - & - \\
\hline XIII.(a) & 22.v.14 & - & 1 & $6 \cdot 4$ & 11 & $4 \cdot 5-8 \cdot 5$ & - & - \\
\hline XIV. & 25.v. 14 & M. & 1 & $6 \cdot 6$ & 43 & $4 \cdot 2-12 \cdot 3$ & - & - \\
\hline $\mathrm{XV}$. & , & S. & 2 & $6 \cdot 6,7 \cdot 7$ & 3 & $9 \cdot 2-9 \cdot 8$ & - & - \\
\hline XVI. & & S. & 4 & $6 \cdot 2-8 \cdot 7$ & 9 & $5-9 \cdot 8$ & - & - \\
\hline XVII. & 3.vi.14 & B. & - & - & 5 & $5 \cdot 3-7 \cdot 5$ & - & - \\
\hline XVIII. & " & B. & 1 & 5 & - & - & - & - \\
\hline XXII. & 11.vi.14 & M. & - & - & 2 & $6 \cdot 4-7$ & - & - \\
\hline XXIII. & & B. & - & - & 6 & $6 \cdot 5-8 \cdot 5$ & - & - \\
\hline XXXVII. & 24.vi.14 & B. & - & - & 2 & $3 \cdot 6-5 \cdot 6$ & - & - \\
\hline LXIV. & 22.vii.14 & B. & - & - & - & - & 1 & $10 \cdot 3$ \\
\hline LXV. & , & B. & - & - & - & - & 1 & $9 \cdot 6$ \\
\hline
\end{tabular}

\section{TABLE XXXIII.}

\section{Solea vUlgaris.}

\begin{tabular}{|c|c|c|c|c|}
\hline $\begin{array}{c}\text { Total number } \\
\text { of hauls } \\
1906-1914 .\end{array}$ & $\begin{array}{l}\text { Number of } \\
\text { hauls in } \\
\text { which the } \\
\text { species } \\
\text { occurs. }\end{array}$ & $\begin{array}{l}\text { Number } \\
\text { of } \\
\text { specimens. }\end{array}$ & Size in $\mathrm{mm}$. & $\begin{array}{l}\text { Average } \\
\text { number } \\
\text { per haul. }\end{array}$ \\
\hline 7 & 2 & 2 & $5 \cdot 7-7 \cdot 5$ & $0 \cdot 3$ \\
\hline 30 & 11 & 19 & $4-10 \cdot 5$ & $0 \cdot 63$ \\
\hline 106 & 5 & 5 & $5-8 \cdot 7$ & 0.05 \\
\hline
\end{tabular}

\section{TABLE XXXIV.}

\section{Solea variegata.}

Month.

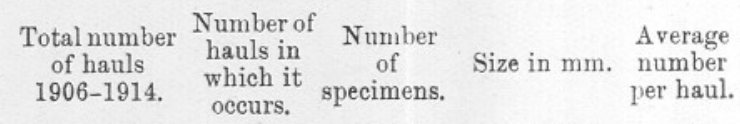

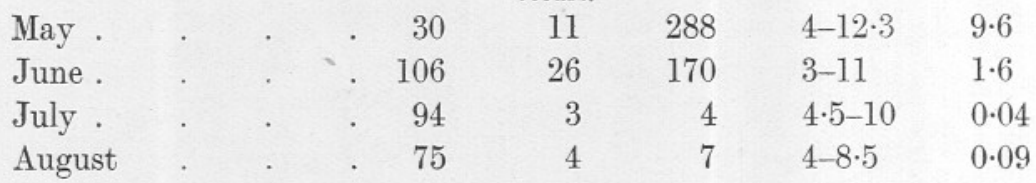




\section{GOBIID $Æ$.}

Gobius sp. Crystallogobius nilssoni Düb. and Kör. Aphya pellucida Nardo.

Table XXXV. gives the record of all the gobies which have not been specifically determined, and the list probably includes many young stages of both Crystallogobius nilssoni and Aphya pellucida. The larger specimens, probably chiefly belong to Gobius minutus Pall., though other species may be included.

Tables XXXVI. and XXXVII. give the records of those specimens, chiefly the larger ones, of Crystallogobius and Aphya which could be determined with some certainty. The separation of the different species has been too incomplete to make it advisable to draw conclusions as to seasonal distribution.

\section{TABLE XXXV.}

RECoRd of Gobius sp.

\begin{tabular}{|c|c|c|c|c|}
\hline $\begin{array}{l}\text { No. of haul. } \\
\text { XI. }\end{array}$ & $\begin{array}{l}\text { Date. } \\
\text { 19.v.14 }\end{array}$ & $\begin{array}{l}\text { Depth. } \\
\text { S. }\end{array}$ & $\begin{array}{c}\text { No. } \\
1\end{array}$ & $\begin{array}{l}\text { Size in } \mathrm{mm} . \\
13\end{array}$ \\
\hline XII. &, & S. & 2 & $9 \cdot 5-12 \cdot 5$ \\
\hline XIII. & , & M. & 5 & $10-12 \cdot 5$ \\
\hline XIII. a & 22.v.14 & - & 63 & $8-14,24$ \\
\hline XIV. & 25.v.14 & M. & 13 & $9 \cdot 6-13 \cdot 3$ \\
\hline $\mathrm{XV}$. & , & S. & 3 & $7-11 \cdot 5$ \\
\hline XVI. & , & S. & 18 & $6 \cdot 5-15$ \\
\hline XX. & 10.vi.14 & S.-M. & 1 & $14 \cdot 5$ \\
\hline XXII. & 11.vi.14 & M-B. & 6 & $12 \cdot 6-14$ \\
\hline XXIII. & " & B. & 5 & $12 \cdot 5-15$ \\
\hline XXV. & 16.vi.14 & B. & 1 & 7 \\
\hline XXVIII. & , & B. & 1 & 7 \\
\hline XLIV. & 29.vi.14 & M. & 3 & $10-14$ \\
\hline XLVI. & 2.viii.14 & S. & 73 & $7-22 \cdot 6$ \\
\hline XLVII. & , & S. & 87 & $6-19 \cdot 5$ \\
\hline XLVIII. & , & M. & 59 & $7-18$ \\
\hline XLIX. & , & M.-B. & 17 & $10-16$ \\
\hline LI. & 6.vii. 14 & B. & 3 & $6-7 \cdot 5$ \\
\hline LIII. & 6.vii. 14 & B. & 1 & $10 \cdot 2$ \\
\hline LIV. & 9.vii. 14 & S. & 3 & $5-7$ \\
\hline LV. & , & M. & 1 & 5 \\
\hline LVI. & , & B. & 1 & 5 \\
\hline
\end{tabular}


TABLE XXXV. (continued.).

\begin{tabular}{|c|c|c|c|c|}
\hline $\begin{array}{l}\text { No. of haul. } \\
\text { LVII. }\end{array}$ & $\begin{array}{l}\text { Date. } \\
\text { 9.vii.14 }\end{array}$ & $\begin{array}{c}\text { Depth. } \\
\text { B. }\end{array}$ & $\begin{array}{c}\text { No. } \\
5\end{array}$ & $\begin{array}{c}\text { Size in mm. } \\
4 \cdot 5-11\end{array}$ \\
\hline LIX. & 15.vii. 14 & M. & 83 & $6-19$ \\
\hline LX. & , & M. & 52 & $7-19$ \\
\hline LXI. & 16.vii. 14 & B. & 82 & $6 \cdot 7-18 \cdot 6$ \\
\hline IXXII. & , & B. & 11 & $5 \cdot 7-27$ \\
\hline LXV. & 22.vii. 14 & B. & 3 & $10-11 \cdot 5$ \\
\hline LXVII. & " & M. & 1 & $6 \cdot 6$ \\
\hline LXVIII. & , & B. & 7 & $3 \cdot 2-8 \cdot 5$ \\
\hline LXXI. & , & B. & 6 & $7 \cdot 5-12$ \\
\hline LXXIII. & 29.vii. 14 & M. & 1 & 10 \\
\hline LXXVII. & , & B. & 6 & $7-10$ \\
\hline LXXVIII. & , & M. & 1 & 6 \\
\hline LXXXI. & , & M. & 3 & $10-11 \cdot 6$ \\
\hline LXXXIII. & , & B. & 1 & 12 \\
\hline LXXXVII. & 4.ix. 14 & M. & 1 & 14 \\
\hline
\end{tabular}

\section{TABLE XXXVI.}

Record of Crystallogobius nilssoni.

\begin{tabular}{|c|c|c|c|c|}
\hline $\begin{array}{l}\text { No. of haul. } \\
\text { IX.(5) }\end{array}$ & $\begin{array}{c}\text { Date. } \\
\text { 15.v.14 }\end{array}$ & $\begin{array}{l}\text { Depth. } \\
\text { B. }\end{array}$ & $\begin{array}{c}\text { No. } \\
2\end{array}$ & $\begin{array}{l}\text { Size in mm. } \\
9-11.5\end{array}$ \\
\hline XII. & 19.v.14 & S. & 6 & $24-27$ \\
\hline XIII. & , & M. & 150 & $17-36$ \\
\hline XIV. & 25.v.14 & M. & 40 & $18-31 \mathrm{ca}$. \\
\hline XV. & , & S. & 11 & $10-27$ \\
\hline XVI. & " & S. & 3 & $11 \cdot 5-28$ \\
\hline XXII. & 11.vi.14 & M.-B. & 4 & $26 \cdot 5-37$ \\
\hline XXXII. & 17.vi.14 & S. & 1 & $\begin{array}{l}\text { Fragment of large } \\
\text { one. }\end{array}$ \\
\hline XLIII. & 29.vi.14 & B. & 3 & 25 са. -30 \\
\hline LVI. & 9. vii.14 & B. & 1 & 27 \\
\hline LVII. & , & B. & 2 & $22-28$ \\
\hline LIX. & 15.vii.14 & M. & 12 & $27-37 \cdot 5$ \\
\hline LX. & 15.vii.14 & M. & 20 & $8-29 \cdot 5$ \\
\hline LXI. & 16.vii.14 & B. & 18 & $26-29$ \\
\hline LXXI. & 22.vii.14 & B. & 8 & $22-38$ \\
\hline LXXIII. & 29.vii.14 & M. & 1 & 12 \\
\hline
\end{tabular}




\section{TABLE XXXVII.}

Record of Aphya pellucida.

\begin{tabular}{|c|c|c|c|c|}
\hline No. of haul. & Date. & Depth. & No. & Size in $\mathrm{mm}$. \\
\hline XIV. & 25.v.14 & M. & 2 & 8,13 \\
\hline XV. & " & S. & 3 & $6 \cdot 6-13$ \\
\hline XVI. & , & S. & 1 & 11.5 \\
\hline XVIII. & 3.vi.14 & B. & 2 & $6-6 \cdot 2$ \\
\hline XX. & 10.vi.14 & S.-M. & 3 & $13 \cdot 5-15$ \\
\hline XXI. & 11.vi.14 & M. & 3 & $11 \cdot 5-16 \cdot 5$ \\
\hline XXII. & 11.vi.14 & M.-B. & 3 & $13 \cdot 2-15 \cdot 3$ \\
\hline XXIII. & 11.vi.14 & B. & 4 & $7 \cdot 6-16$ \\
\hline XXXVII. & 24.vi.14 & B. & 3 & $6 \cdot 5-8 \cdot 5$ \\
\hline XLIII. & 29.vi.14 & B. & 2 & 10 ca. -12 \\
\hline LXIII. & 22.vii.14 & B. & 50 & $7 \cdot 5-11$ \\
\hline LXIV. & 22.vii.14 & B. & 1 & 10 \\
\hline LXV. & ", & B. & 6 & $10 \cdot 5-12 \cdot 5$ \\
\hline LXVI. & , & M. & 1 & 10 \\
\hline LXXV. & 29.vii.14 & B. & 1 & 11 \\
\hline LXXXII. & , & M. & 1 & $11 \mathrm{ca}$. \\
\hline LXXXVI. & 12.viii.14 & B.-M. & 1 & 11 \\
\hline
\end{tabular}

\section{CYCLOPTERIDA.}

\section{Cyclopterus lumpus $\mathrm{L}$.}

One specimen of the lump sucker was obtained in the young-fish trawl in 1914. It was found in Haul XLI., $3 \frac{1}{2}$ miles S.W. by W. of the Eddystone, a bottom haul made on June 26th, 1914. The length of the specimen was $16.5 \mathrm{~mm}$. Clark records one specimen $18 \mathrm{~mm}$. long in 1913 .

\section{TRIGLID A.}

\section{Trigla gurnardus $\mathrm{L}$. T. hirundo $\mathrm{Bl}$.}

The characters by means of which post-larval stages of $T$. gurnardus and $T$. hirundo may be distinguished have been pointed out by Clark (1914) in his report on the post-larval teleosteans of Plymouth. The specimens which were most numerous in the 1914 material belong to the T. gurnardus type, with long pectoral fins which are pigmented chiefly on the posterior half of the fin. From specimens of this type young $T$. hirundo with short, broad pectorals pigmented over the whole surface, are easily and definitely distinguishable. 
Clark refers to specimens appearing in August and September which he thinks are quite distinct from $T$. gurnardus and $T$. hirundo, and have very little pigment. These he regards as probably belonging to the species T. lineata. A few specimens amongst the 1914 material, which I have included under the gurnardus type, very closely approach the forms which Clark thus regards as $T$. lineata, the amount of pigment on the pectoral fins being small, although the fins are long. The variation in the amount of pigment seen in preserved material, especially when the preservation is not very good, is considerable, and seems to me to make it impossible to assign every specimen to a particular species with any degree of certainty until some more definite character can be used for purposes of investigation.

It must be borne in mind too that the species which as an adult is perhaps the most numerous on the grounds in the neighbourhood where most of the hauls have been made is $T$. cuculus, and so far as I am aware the young stages of that form have never been recognised. It is possible, therefore, that this species may be included amongst the forms with long pectorals pigmented on the posterior half, which are here included under Trigla sp., and amongst those which Clark recorded as T. gurnardus. A fourth species, $T$. lyra, is occasionally found in the western part of the English Channel, concerning the young stages of which nothing is known.

Unfortunately the numerical characters, such as number of fin rays and vertebræ, of these gurnards are all so similar that they cannot be used for discriminating the species in these young stages.

\section{TABLE XXXVIII.}

\section{RECORD OF TRIgla SP.}

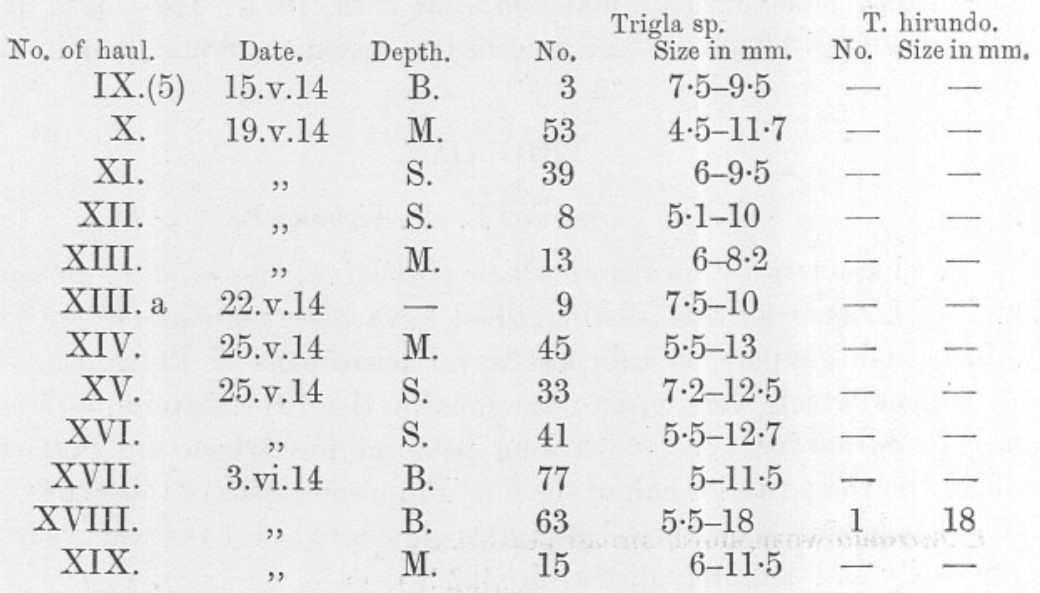




\section{TABLE XXXVIII. (continued.).}

\begin{tabular}{|c|c|c|c|c|c|c|}
\hline No. of haul. & Date. & Depth. & No. & $\begin{array}{l}\text { Trigla sp. } \\
\quad \text { Size in mm. }\end{array}$ & $\begin{array}{l}\text { T. } \\
\text { No. }\end{array}$ & $\begin{array}{l}\text { hirundo. } \\
\text { Size in } m n\end{array}$ \\
\hline $\mathrm{XX}$ & 10.vi.14 & S.-M. & 4 & $9-10 \cdot 8$ & - & - \\
\hline XXI. & 11.vi.14 & M. & 9 & $8 \cdot 7-10 \cdot 5$ & 一 & - \\
\hline XXII. & , & M. - B. & 12 & $8 \cdot 2-15$ & - & - \\
\hline XXIII. & , & B. & 24 & $7-11 \cdot 5$ & - & - \\
\hline XXIV. & 16.vi.14 & B. & 2 & $8,8.5$ & - & - \\
\hline XXV. & , & B. & 1 & $10 \mathrm{ca}$. & 一 & - \\
\hline XXVI. & , & B. & 19 & $5 \cdot 6-16 \cdot 5$ & - & - \\
\hline XXVII. & , & M. & 5 & $7-9$ & - & 一 \\
\hline XXX. & 17.vi.14 & M. & 2 & $7 \cdot 7-8 \cdot 5$ & - & - \\
\hline XXXI. & , & M. & 2 & $7 \cdot 5-8 \cdot 4$ & - & 一 \\
\hline XXXV. & 19.vi.14 & M. & 2 & $12-13$ & - & 一 \\
\hline XXXVI. & 24.vi.14 & B. & 1 & $7 \cdot 7$ & 1 & $10 \cdot 5$ \\
\hline XXXVII. &, & B. & 3 & $6 \cdot 8-7 \cdot 7$ & - & - \\
\hline XXXVIII. & , & M. & 1 & 11 & 1 & 7 \\
\hline XLII. & 29.vi.14 & B. & 1 & $10 \cdot 5$ & - & - \\
\hline XLIII. & , & B. & 7 & $6 \cdot 5-12$ & - & - \\
\hline XLIV. & , & M. & 2 & $9-13 \cdot 5$ & - & - \\
\hline XLV. & , & - & - & - & 1 & $12 \mathrm{ca}$. \\
\hline XLVI. & 2.vii.14 & S. & 5 & $9 \cdot 5-10 \cdot 5$ & - & - \\
\hline XLVII. & 2.vii.14 & S. & 1 & $10 \cdot 8$ & - & - \\
\hline LVIII. & 9.vii.14 & M. & 2 & $13-16$ & - & - \\
\hline LX. & 15.vii.14 & M. & 1 & 12 & - & - \\
\hline LXVIII. & 22.vii.14 & B. & - & - & 2 & $8-10$ \\
\hline LXIX. & $"$ & S. & - & 一 & 1 & $9 \cdot 5$ \\
\hline LXXIII. & 29.vii.14 & M. & 1 & 11 & - & - \\
\hline LXXIV. & ", & M. & - & - & 1 & $11 \mathrm{ca}$ \\
\hline LXXV. & ", & B. & 1 & 10 & - & - \\
\hline LXXVI. & , & M. & 1 & $11 \cdot 7$ & - & - \\
\hline LXXVIII. & ,.. & M. & 2 & $9-19$ & - & - \\
\hline LXXXV. & 12.viii.14 & M. & 5 & $13 \cdot 5-19$ & - & 一 \\
\hline
\end{tabular}




\section{TRACHINID $A$.}

Trachinus vipera Cuv.

The 1914 records are given in Table XXXIX. and monthly summaries for the period 1906-14 in Table XL. In 1914 no specimens were observed during May and the first half of June, the first record being on June 16th. Over the whole period the average number per haul is highest in July and August, being slightly though perhaps not significantly higher in August than in July. In September there is a rapid disappearance of specimens in the hauls.

No specimens of Trachinus draco were recognised in the 1914 material. Clark obtained four specimens of this species in August and September, 1913.

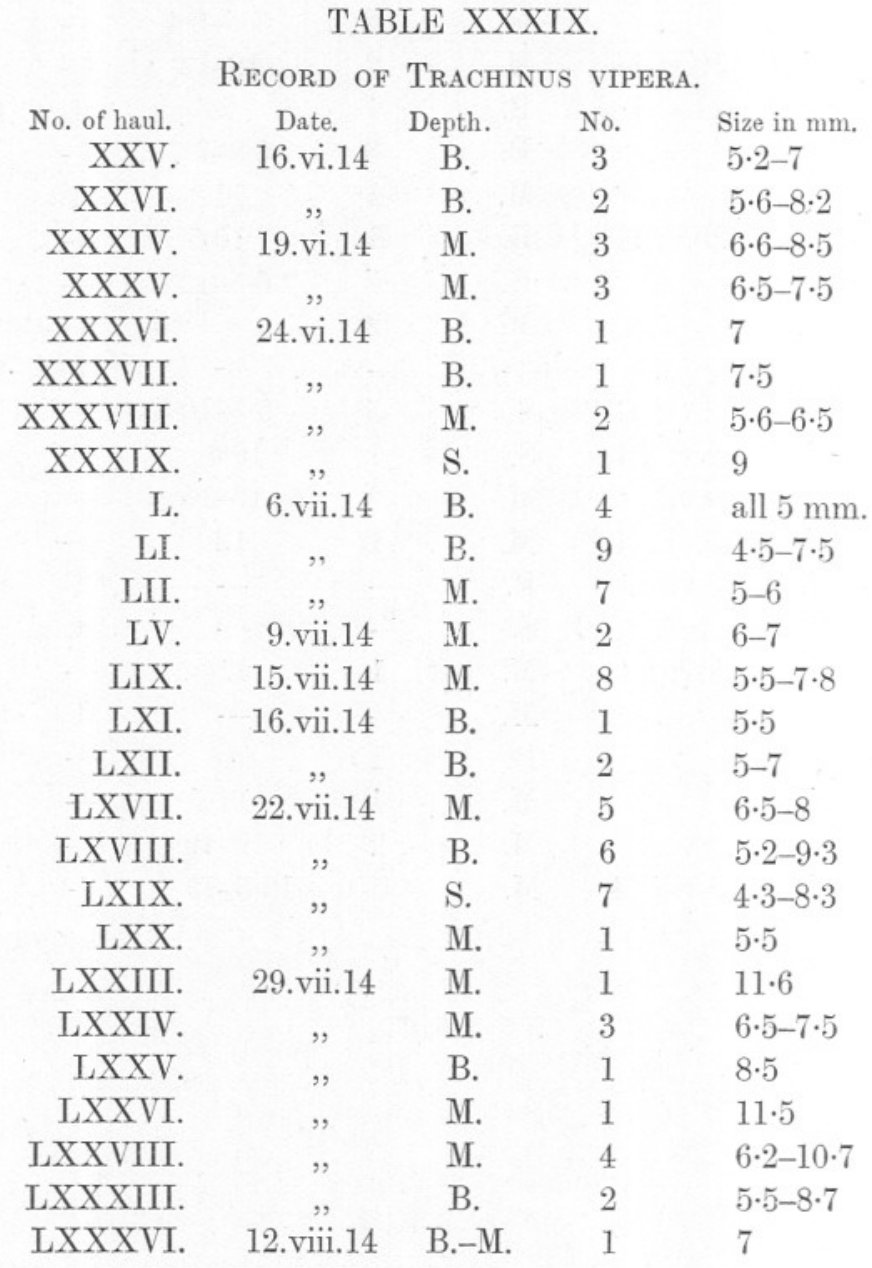


TABLE XL.

Trachinus VIPERA.

\begin{tabular}{|c|c|c|c|c|c|c|c|}
\hline Month. & & & $\begin{array}{c}\text { Total number } \\
\text { of hauls } \\
1906-1914 .\end{array}$ & $\begin{array}{l}\text { Number of } \\
\text { hauls in } \\
\text { which it }\end{array}$ & $\begin{array}{c}\text { Number } \\
\text { of } \\
\text { specimens. }\end{array}$ & Size in $\mathrm{mm}$. & $\begin{array}{l}\text { Average } \\
\text { number } \\
\text { per haul. }\end{array}$ \\
\hline April & . & . & 7 & 1 & 1 & $3 \cdot 5$ & $0 \cdot 1$ \\
\hline May . & . & • & 30 & 1 & 1 & $3 \cdot 5$ & $0 \cdot 03$ \\
\hline June . & . & - & . 106 & 22 & 80 & $2 \cdot 5-9$ & $0 \cdot 75$ \\
\hline July . & . & • & 94 & 45 & 335 & $3-11 \cdot 6$ & $3 \cdot 6$ \\
\hline August & . & . & 75 & 52 & 292 & $2 \cdot 7-18$ & $3 \cdot 9$ \\
\hline September & & . & 85 & 26 & 42 & $3 \cdot 5-18$ & $0 \cdot 5$ \\
\hline
\end{tabular}

\section{CALLIONYMID E.}

Callionymus lyra $\mathrm{L}$.

Post-larval dragonets are more constantly met with in the hauls and occur in greater numbers than any other species of teleostean, being specially abundant in May and June. The 1914 records are given in Table XLI., and the monthly summaries in Table XLII.

\section{TABLE XLI.}

\section{Record of Callionymus lyRa.}

$\begin{array}{cccrc}\text { No. of haul. } & \text { Date. } & \text { Depth. } & \text { No. } & \text { Size in mm. } \\ \text { V. } & 29 . i v .14 & \text { B. } & 5 & 4-7 \\ \text { VI. } & , & \text { M. } & 4 & 5-7 \\ \text { VII. } & , & \text { S. } & 5 & 3-6 \\ \text { VIII. (1) } & \text { 8.v.14 } & \text { M. } & 1 & 6 \cdot 3 \\ \text { IX. (1) } & 15 . v .14 & \text { M. } & 67 & 5-7 \cdot 5 \\ \text { IX. (5) } & , & \text { B. } & 108 & 4-7 \\ \text { XII. } & 19 . v .14 & \text { S. } & 5 & 5-10 \cdot 5 \\ \text { XIII. } & , & \text { M. } & 20 & 4 \cdot 5-11 \\ \text { XIII.a } & 22 . v .14 & - & 34 & 5-9 \\ \text { XIV. } & 25 . v .14 & \text { M. } & 4 & 5 \cdot 5-7 \\ \text { XV. } & , & \text { S. } & 4 & 8-10 \cdot 5 \\ \text { XVI. } & " & \text { S. } & 3 & 5 \cdot 5-6 \\ \text { XVII. } & 3 . v i .14 & \text { B. } & 105 & 4-7 \\ \text { XVIII. } & , & \text { B. } & 59 & 3 \cdot 5-7 \\ \text { XIX. } & , " & \text { M. } & 15 & 4 \cdot 5-8 \\ \text { XX. } & 10 . v i .14 & \text { S.-M. } & 2 & 5 \cdot 5-6 \cdot 3 \\ \text { XXI. } & 11 . v i .14 & \text { M. } & 9 & 5 \cdot 2-11 \\ \text { XXII. } & , " & \text { M.-B. } & 16 & 6-12\end{array}$


TABLE XLI. (continued).

\begin{tabular}{|c|c|c|c|c|}
\hline $\begin{array}{l}\text { No. of haul. } \\
\text { XXIII. }\end{array}$ & $\begin{array}{l}\text { Date. } \\
\text { 11.vi.14 }\end{array}$ & $\begin{array}{l}\text { Depth. } \\
\text { B. }\end{array}$ & $\begin{array}{r}\text { No. } \\
41\end{array}$ & $\begin{array}{r}\text { Size in } \mathrm{mm} \\
5-13.5\end{array}$ \\
\hline XXIV. & 16.vi.14 & B. & 2 & $6 \cdot 7-10 \cdot 2$ \\
\hline XXV. & , & B. & 27 & $3 \cdot 8-8$ \\
\hline XXVII. & " & M. & 1 & 7 \\
\hline XXIX. & 17.vi.14 & B. & 1 & $7 \cdot 3$ \\
\hline XXX. & , & M. & 14 & $3 \cdot 7-8 \cdot 3$ \\
\hline XXXI. & , & M. & 30 & $3-9$ \\
\hline XXXII. & , & S. & 17 & $4-6$ \\
\hline XXXIII. & 19.vi.14 & M. & 1 & $7 \cdot 7$ \\
\hline XXXIV. & ", & M. & 1 & 7 \\
\hline XXXV. & , & M. & 10 & $5 \cdot 5-8 \cdot 7$ \\
\hline XXXVI. & 24.vi.14 & B. & 2 & $3 \cdot 2-6 \cdot 6$ \\
\hline XXXVII. & , & B. & 54 & $4 \cdot 5-8$ \\
\hline XLII. & 29.vi.14 & B. & 11 & $7-8.5$ \\
\hline XLIII. & ", & B. & 37 & $5 \cdot 5-8 \cdot 7$ \\
\hline XLIV. & $"$ & M. & 13 & $5 \cdot 5-8$ \\
\hline XLV. & ", & S. & 1 & 6 \\
\hline XLVI. & 2.vii.14 & S. & 165 & $6-12$ \\
\hline XLVII. & , & S. & 98 & $5 \cdot 5-12 \cdot 2$ \\
\hline XLVIII. & $"$ & M. & 94 & $4-12 \cdot 2$ \\
\hline XLIX. & ", & M.-B. & 47 & $5 \cdot 5-11 \cdot 5$ \\
\hline $\mathrm{L}$. & 6.vii.14 & B. & 2 & $10-13.5$ \\
\hline LI. & , & B. & 2 & $7 \cdot 5-9$ \\
\hline LIV. & 9.vii.14 & S. & 2 & $6-6.5$ \\
\hline LV. & " & M. & 1 & $5 \cdot 3$ \\
\hline LVI. & $"$ & B. & 1 & 6 \\
\hline LVII. & $"$ & B. & 3 & $6 \cdot 7-7 \cdot 1$ \\
\hline LIX. & 15.vii.14 & M. & 6 & $6 \cdot 5-8 \cdot 5$ \\
\hline LXI. & 16.vii.14 & B. & 4 & $7 \cdot 5-11$ \\
\hline LXII. & ", & B. & 2 & $5-6$ \\
\hline LXVII. & 22.vii.14 & M. & 1 & $6 \cdot 5$ \\
\hline LXVIII. & " & B. & 10 & $4 \cdot 5-7 \cdot 3$ \\
\hline LXIX. & $"$ & S. & 1 & 6.5 \\
\hline LXX. & " & M. & 1 & 6 \\
\hline LXXIII. & 29.vii.14 & M. & 8 & $6 \cdot 5-8$ \\
\hline LXXIV. & ", & M. & 3 & $6 \cdot 5-7 \cdot 5$ \\
\hline LXXVI. & ", & M. & 2 & $9 \cdot 2$ \\
\hline LXXVII. & " & B. & 4 & $6 \cdot 5-8 \cdot 5$ \\
\hline LXXXIV. & " & B. & 1 & 8 \\
\hline
\end{tabular}




\section{TABLE XLII.}

\section{Callionymus lyra.}

Month.

\begin{tabular}{|c|c|c|c|}
\hline $\begin{array}{l}\text { Total number } \\
\text { of hauls } \\
1906^{\circ}-1914 \text {. }\end{array}$ & $\begin{array}{l}\text { Number of } \\
\text { hauls in } \\
\text { which it } \\
\text { occurs. }\end{array}$ & $\begin{array}{c}\text { Number } \\
\text { of } \\
\text { specimens. }\end{array}$ & Size in $\mathrm{mm}$. \\
\hline
\end{tabular}

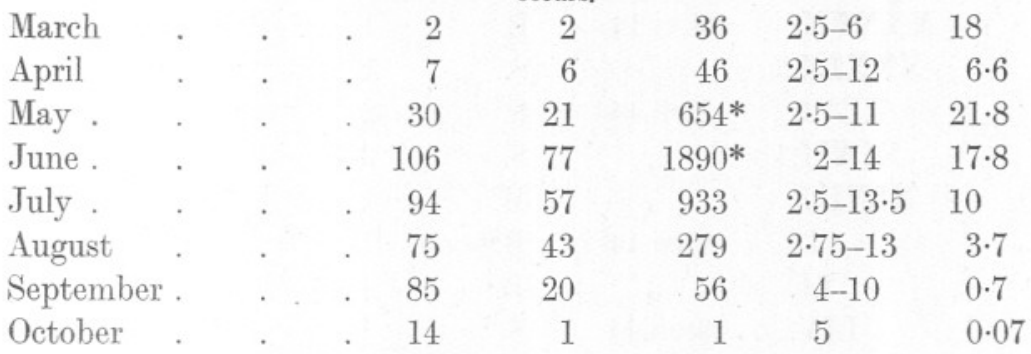

\section{GOBIESOCID $A$.}

\section{Lepadogaster.}

Eighteen post-larval specimens were obtained in 1914, thirteen of which occurred in July. According to Clark's records (1914) specimens may occur from June to September.

\section{TABLE XLIII.}

\section{RECORD OF LEPADOGASTER SP.}

$\begin{array}{rcccl}\text { No. of haul. } & \text { Date. } & \text { Depth. } & \text { No. } & \text { Size in mm. } \\ \text { XXIII. } & \text { 11.vi.14 } & \text { B. } & 1 & 10 \cdot 5 \\ \text { XLVI. } & \text { 2.vii.14 } & \text { S. } & 5 & 10-12 \\ \text { XLVII. } & , & \text { S. } & 1 & 11 \cdot 2 \\ \text { XLVIII. } & , & \text { M. } & 3 & 8 \cdot 6-11 \cdot 7 \\ \text { LV. } & 9 . \text { vii.14 } & \text { M. } & 1 & 6 \cdot 5 \\ \text { LVII. } & , & \text { B. } & 2 & 7 \cdot 5 \\ \text { LIX. } & \text { 15.vii.14 } & \text { M. } & 1 & 10 \\ \text { LXXXVI. } & \text { 12.viii.14 } & \text { B. }- \text { M. } & 4 & 10-11 \cdot 2\end{array}$

\section{BLENNIID Æ.}

Probably two species at least are represented in the material, Blennius pholis L. and Blennius ocellaris L., but I have not succeeded in separating. them with certainty. The records are shown in Table XLIV.

* m. (=many) has been counted as 50, and v.m. (=very many) as 100. The figures for May and June are therefore approximations only 


\section{TABLE XLIV.}

Record of Blennius Sp.

\begin{tabular}{|c|c|c|c|c|}
\hline $\begin{array}{l}\text { No. of haul. } \\
\text { XXV. }\end{array}$ & $\begin{array}{l}\text { Date. } \\
\text { 16.vi.14 }\end{array}$ & $\begin{array}{l}\text { Depth. } \\
\text { B. }\end{array}$ & No. & $\begin{array}{l}\text { Size in mm. } \\
6.5\end{array}$ \\
\hline XXVII. & , & M. & 1 & 7 \\
\hline XXXVII. & 24.vi.14 & B. & 1 & $5 \cdot 5$ \\
\hline XXXIX. & $"$ & S. & 1 & 9 \\
\hline XLVI. & 2.vii.14 & S. & 2 & $8-9$ \\
\hline XLVII. & , & S. & 2 & $8 \cdot 5-9 \cdot 5$ \\
\hline XLVIII. & , & M. & 1 & $12 \cdot 5$ \\
\hline L. & 6.vii.14 & B. & 1 & $6 \cdot 4$ \\
\hline LI. & $"$ & B. & 1 & $7 \cdot 5$ \\
\hline LIV. & 9.vii.14 & S. & 1 & 17 \\
\hline$"$ & ", & " & 6 & $6-8 \cdot 5$ \\
\hline LV. & $"$ & M. & 1 & 6 \\
\hline LVIII. & , & М. & 2 & $12-13 \cdot 5$ \\
\hline LXIV. & 22.vii.14 & B. & 2 & 17.5 \\
\hline LXV. & , & B. & 1 & 17 \\
\hline LXVIII. & " & B. & 3 & $7-9 \cdot 8$ \\
\hline LXXIII. & 29.vii.14 & M. & 1 & 12 \\
\hline LXXV. & ", & B. & 1 & 7 \\
\hline LXXV. & , & B. & 1 & $8 \cdot 5$ \\
\hline LXXXIII. & , & B. & 1 & 8 \\
\hline IXXXXVII. & 4.ix.14 & M. & 4 & $8 \cdot 3-11$ \\
\hline
\end{tabular}

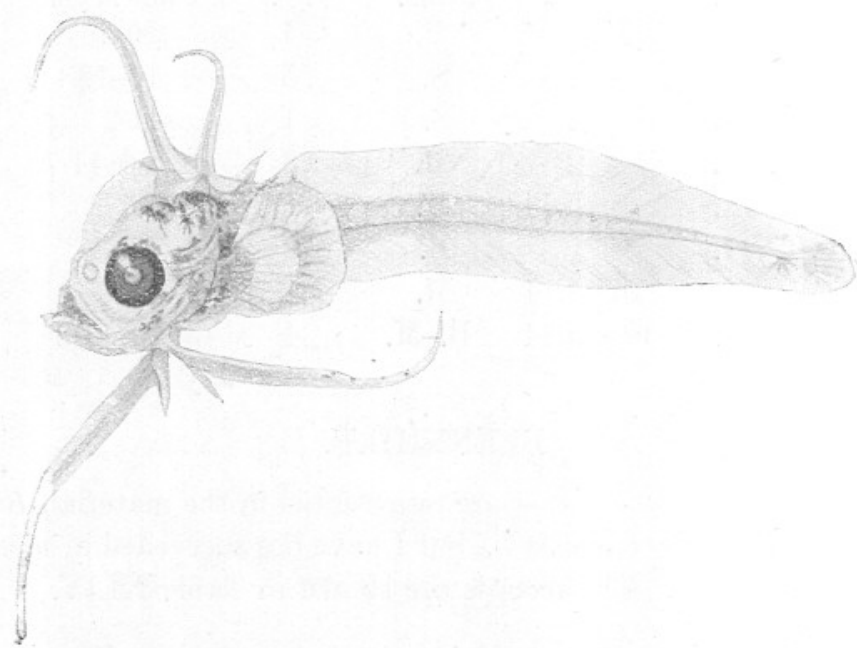

FIG. 8.-Lophius piscatorius L. Length $6 \cdot 2 \mathrm{~mm}$. July 16th, 1914 . 


\section{PEDICULATI.}

\section{Lophius piscatorius L.}

One specimen of an early stage, $6 \cdot 2 \mathrm{~mm}$. long was found in Haul LXII., taken near the bottom 7 miles west of Rame Head on July 16th, 1914. A figure of this specimen drawn by Mrs. Sexton is reproduced as Fig. 8 . The great resemblance of this figure with Emery's figure, which is reproduced by Ehrenbaum in Nordisches Plankton, p. 303, Fig. 108, b, and ascribed by both authors to Macrurus, may be pointed out. It seems to me very probable that that figure should really be assigned to Lophius.

The larva of Lophius piscatorius is figured by Danois (1913, p. 164, Fig. 319). Ehrenbaum (1905-9) reproduces Agassiz and Whitman's figures of American specimens.

\section{SUMMARY.}

Table XLV. is perhaps of interest, as showing the composition of the catch obtained with the young-fish trawl at different times of the year. It has been obtained by combining certain groups of hauls made in 1914 in the offshore waters outside Plymouth, all of them being beyond the 20-fathom line. As far as the conditions are concerned therefore the different groups are fairly comparable. The figure given for each species is the average number of specimens per haul for the group. It will be seen that after. June the number of species present as well as the average number per haul are both very much reduced.

\section{TABLE XLV.}

\section{Averages per Haul in Different Groups of Hauls.}

\begin{tabular}{|c|c|c|c|c|c|c|c|c|}
\hline & & $\begin{array}{l}\text { X.-XIII. } \\
\text { S. of } \\
\text { Eddystone } \\
\text { May 19,'14. } \\
27-89 \text { fms. }\end{array}$ & $\begin{array}{l}\text { XIV.-XVI } \\
\text { S. of } \\
\text { Eddyston. } \\
\text { May 25, }{ }^{2} 14 . \\
35-37 \text { fms. }\end{array}$ & $\begin{array}{l}\text { XVII.- } \\
\text { XXIII. } \\
\text { W. of } \\
\text { Rame } \\
\text { Rune } 311, \\
1914 \text {. } \\
196-27 \text { fms. }\end{array}$ & $\begin{array}{c}\text { XXXV. } \\
\text { to XLI. } \\
\text { Eddystone } \\
\text { June 19-26, } \\
1914 . \\
23-39 \text { fms. }\end{array}$ & $\begin{array}{l}\text { LXVII. } \\
\text { to LXX. } \\
\text { Eddystone } \\
\text { July } 22,{ }^{2} 14 \\
32-38 \text { fms. }\end{array}$ & $\begin{array}{l}\text { LXXIII. } \\
\text { to } \\
\text { LXXIII. I } \\
\text { eEddystone } \\
\text { July } 29,14 . \\
20-35 \text { fms. A }\end{array}$ & $\begin{array}{l}\text { LXXXV. } \\
\text { and } \\
\text { aXXXI. } \\
\text { W. of } \\
\text { Rame } \\
\text { Aug. 12,'14 } \\
26-27 \text { fms. }\end{array}$ \\
\hline Clupea & . & . 217 & v.m. & v.m. & 11 & 11 & 2 & - \\
\hline Ammodytes & . & $0 \cdot 7$ & 1 & 4 & 3 & 7 & 3 & - \\
\hline Gadus pollachius . & . & 2 & - & - & - & $0 \cdot 2$ & - & - \\
\hline " merlangus . & . & 6 & 13 & 9 & 0.5 & - & - & - \\
\hline$"$ minutus. & . & 44 & 47 & 2 & 4 & $0 \cdot 2$ & $0 \cdot 2$ & - \\
\hline , luscus & . & 3 & 6 & $0 \cdot 4$ & $0 \cdot 3$ & - & - & - \\
\hline Molva molva & . & $0 \cdot 2$ & $0 \cdot 7$ & $0 \cdot 4$ & $0 \cdot 2$ & - & 一 & - \\
\hline Raniceps raninus . & . & . & - & - & - & - & 0.2 & 一 \\
\hline Onos mustelus : & : & 3 & 9 & $0 \cdot 7$ & $0 \cdot 7$ & - & $0 \cdot 2$ & - \\
\hline Labrus bergylta . & . & 0.5 & 2 & 3 & - & - & $0 \cdot 2$ & 2 \\
\hline Labrus mixtus & . & $0 \cdot 2$ & 1 & $0 \cdot 7$ & $0 \cdot 2$ & 0.5 & - & - \\
\hline
\end{tabular}




\section{TABLE XLV. (continued).}

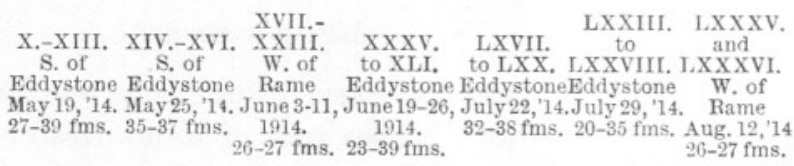

Ctenolabrus rupestris

Scomber scomber . . - $\quad 28$

Pleuronectes limanda $\quad$. $\quad 29 \quad 358$

," microcephalus

Arnoglossus laterna

\begin{tabular}{rr}
04 & 15 \\
0.5 & 8 \\
- & - \\
\hline
\end{tabular}
, laevis

Scophthalmus norvegicus

Zeugopterus punctatus . , unimaculatus

Solea vulgaris . . $\quad 0 \cdot 2$ ,, variegata . . 36

Gobius sp. . $\quad . \quad$. 2

Crystallogobius nilssoni $\quad 39$

Aphya pellucida . . -

Cyclopterus lumpus . -

Trigla gurnardus . . 28

hirundo 40

Trachinus vipera $\cdot$ -

Callionymus lyra . $\quad . \quad 6$

Lepadogaster

Blennius fms. 23-39 fms.

\begin{tabular}{ccccc}
\hline 7 & $0 \cdot 5$ & $0 \cdot 2$ & $0 \cdot 5$ & $0 \cdot 5$ \\
22 & 2 & 0.5 & - & - \\
8 & $0 \cdot 2$ & - & - & - \\
21 & $0 \cdot 5$ & $0 \cdot 2$ & $0 \cdot 2$ & - \\
- & 3 & 3 & 6 & 1 \\
$0 \cdot 3$ & - & - & $0 \cdot 3$ & - \\
19 & - & $0 \cdot 2$ & $0 \cdot 2$ & $0 \cdot 5$ \\
$0 \cdot 7$ & - & - & - & - \\
1 & - & - & - & - \\
$0 \cdot 1$ & - & - & - & - \\
2 & $0 \cdot 3$ & - & - & - \\
2 & - & 2 & 1 & - \\
$0 \cdot 6$ & - & - & $0 \cdot 2$ & - \\
2 & $0 \cdot 5$ & - & $0 \cdot 2$ & 0.5 \\
\hline- & $0 \cdot 2$ & - & - & - \\
29 & 1 & - & 1 & 2 \\
$0 \cdot 1$ & $0 \cdot 3$ & 1 & $0 \cdot 2$ & - \\
\hline- & 1 & 5 & 2 & $0 \cdot 5$ \\
35 & 11 & 3 & 3 & - \\
$0 \cdot 1$ & - & - & - & 2 \\
- & $0 \cdot 3$ & 1 & 0.5 & -
\end{tabular}

\section{LITERATURE.}

1887. Matthews, J. Duncan.-Note on the Ova, Fry and Nest of the Ballan Wrasse. 5th Ann. Rep. Fish. Bd. Scotland.

1888. Raffaele, F.-Mitteil. Zool. Sta. Neapel. VIII.

1899. HoLt, E. W. L.-Recherches sur la reproduction des pois ons osseux. Ann. Mus. d'Hist. Nat. Marseille. Zoologie. T. V.

1905-9. Ehrenbaum, E.-Eier und Larven von Fischen. Nordisches Plankton. IV. and X.

1910. Hefford, A. E.-Notes on Teleostean Ova and Larvæ observed at Plymouth in Spring and Summer, 1909. Journ. Mar. Biol. Assoc. IX. p. 1.

1913. DAnors, E.-Contribution à l'étude systématique et biologique des poissons de la manche occidentale. Paris. Masson et Cie.

1914. Clark, R. S.-General Report on the Larval and Post-Larval Teleosteans in Plymoutl Waters. Journ. Mar. Biol. Assoc. X. p. 327 . 